GRØNLANDS GEOLOGISKE UNDERS $\varnothing G E L S E$ G E U S RAPPORT NR. 12

Report file no.

The Geological Survey of Greenland

22334

Report no. 12

The chromite deposits of the Fiskenæsset region, West Greenland

by

Martin Ghisler and Brian F. Windley 


\section{Grønlands Geologiske Undersøgelse \\ Østervoldgade 5-7, Copenhagen $\mathrm{K}$ \\ Recent publications}

\section{Bulletins}

reprinted from Meddelelser om Gronland

No. 62 Geomorphological observations on Sermersôq; a contribution to the geomorphology of S. Greenland. 1965 by Oen Ing Soen.

No. 63 Eudidymite and epididymite from the Ilímaussaq alkaline intrusion, South Greenland. 1966 by E. I. Semenov and H. Sørensen.

No. 64 Superposed deformations of the Ketilidian gneisses of the Sârdloq area, South Greenland. 1966 by B. F. Windley.

No. 65 The pattern of folding in an area of migmatites between Neria and Qasigialik fjords, South-West Greenland. 1967 by F. Kalsbeek.

No. 66 L'évolution du socle précambrien dans la région de Qagssimiut, Groënland méridional. 1967 by S. N. Ayrton and M. Burri.

No. 67 Precambrian organisms and the isotopic composition of organic remains in the Ketilidian of South-West Greenland. 1967 by E. Bondesen, K. Raunsgaard Pedersen and O. Jørgensen.

No. 68 Contributions to the mineralogy of Ilímaussaq. Nos 3-7. 1967.

No. 69 Basic and intermediate igneous activity and its relationships to the evolution of the Julianehåb granite, South Greenland. 1967 by J. H. Allaart.

No. 70 Plutonic development of the Ilordleq area, South Greenland. Part II : Latekinematic basic dykes. 1968 by J. Watterson.

\section{Miscellaneous Papers}

reprinted from various journals

No. 50 The alkali feldspars from microsyenitic dykes of southern Greenland. 1966 by H. G. Scharbert.

No. 51 Notes on the Julianehåb granite of Eqaluit peninsula, Julianehåb district, Southern Greenland. 1966 by H. G. Scharbert.

No. 52 The stratigraphy and structure of the Precambrian rocks of the Umanak area, West Greenland. 1967 by G. Henderson and T. C. R. Pulvertaft.

No. 53 Submicroscopic shell structures in early growth-stages of Maastrichtian ammonites (Saghalinites and Scaphites). 1967 by T. Birkelund.

No. 54 On the classification of the West Greenland anorthosites. 1967 by B.F.Windley.

No. 55 Tectonic levels in the Precambrian of South Greenland. 1967 by A. Escher.

No. 56 Feldspathic inclusions in the Gardar igneous rocks of South Greenland and their relevance to the formation of major anorthosites in the Canadian Shield. 1967 by D. Bridgwater. 


\title{
THE CHROMITE DEPOSITS OF THE FISKENÆSSET REGION, WEST GREENLAND
}

\author{
by \\ MARTIN GHISLER and BRIAN F. WINDLEY
}

With 10 figures and 3 maps 


\section{CONTENTS}

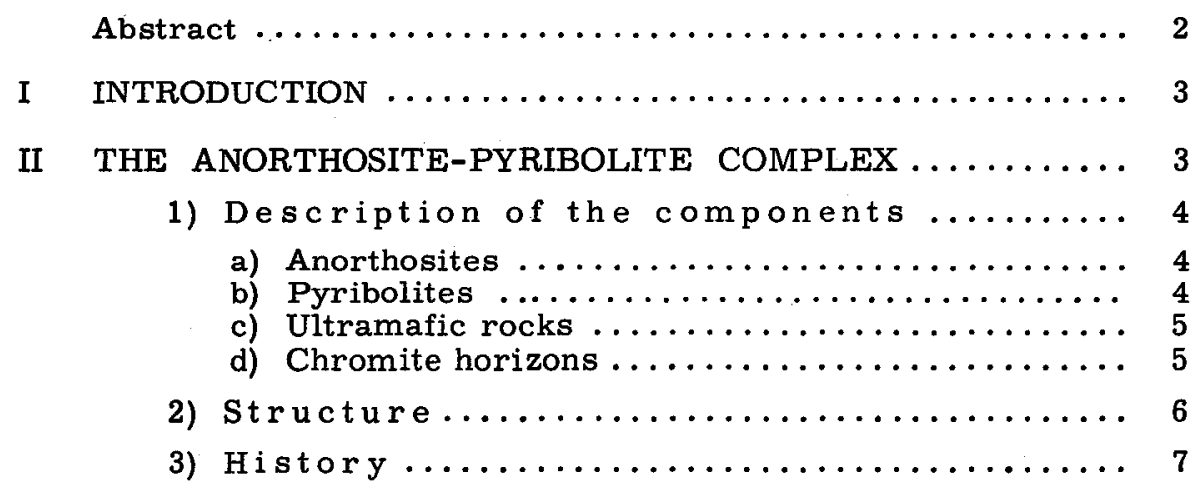

III ECONOMIC GEOLOGY $\ldots \ldots \ldots \ldots \ldots \ldots \ldots \ldots \ldots \ldots$

1) General description of the chromite.... 9

2) The chromite-bearing anorthosite horizons ....................... 11

a) Lichtenfels-Fiskenæsset............... 11

b) Qeqertarssuatsiaq-Mánisat.............11

c) Taseq ....................... 14

d) Kangârssuk-Angnertussoq-Tasiussâ ......... 14

3) Ore microscopy ................. 16

a) Chromite in anorthosite .............. 16

b) Chromite and sulphides in bronzitite ........ 18

4) Petrology of the chromite-bearing rocks 18

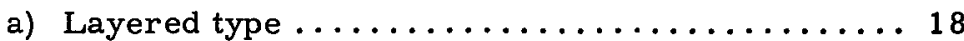

b) Augen type ..................... 19

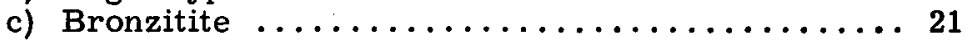

5) The analytical programme $\ldots \ldots \ldots \ldots \ldots 21$

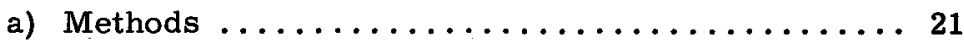

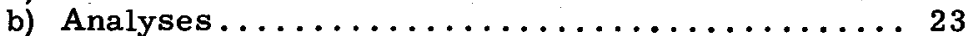

c) Discussion of results ................ 28

d) Classification of the chromite ........... 29

6) Economic potential ............... 31

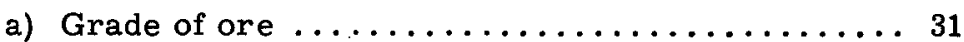

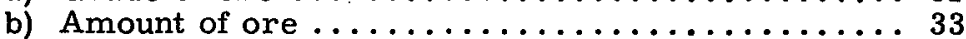

c) Comparison with other chrome ores $\ldots \ldots \ldots \ldots 34$

d) Accessibility .................... 35

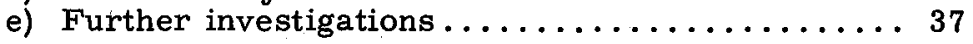

References .......................... 38 


\begin{abstract}
The chromite deposits of the Fiskenæsset region occur in anorthosites, which together with intercalated pyribolites (hypersthene amphibolites) and subsidiary pyroxenites and peridotites occur in the gneisses as horizons belonging to a folded and metamorphosed stratiform complex which has a maximum thickness of $2 \mathrm{~km}$.

The chromite occurs in horizons which average $0.5-3 \mathrm{~m}$ in width, reaching a maximum of $20 \mathrm{~m}$, and consist of alternating anorthosite and chromitite layers, usually between 0.5 and $10 \mathrm{~cm}$ wide. Chromite horizons occur in almost all of the anorthosite horizons in the region which have a minimum exposed length of $125 \mathrm{~km}$.

$175 \mathrm{X}$-ray fluorescence analyses show that the $\mathrm{Cr}_{2} \mathrm{O}_{3}$ content of the chromite varies between $26 \%$ and $36 \%$, averaging $32.7 \%$. The total iron oxide content varies between $28 \%$ and $42 \%$, averaging $31.8 \%$ (as $\mathrm{FeO}$ ), with the result that the $\mathrm{Cr}: \mathrm{Fe}$ ratio varies between 0.66 and 1.05 , averaging 0.93 . The chromite has a high $\mathrm{V}_{2} \mathrm{O}_{5}$ content varying from $0.2 \%$ to $0.5 \%$ with an average value of $0.3 \%$.

The chromite horizons occur along the shores of the fjords or only a few kilometres from the coast in easily accessible terrain that rarely exceeds $500 \mathrm{~m}$ in altitude. Fiskenæsset harbour is ice-free for the whole year.
\end{abstract}




\section{INTRODUCTION}

Except for the well-known type locality for sapphirine in Fiskenæsset harbour and for an unpublished reconnaissance by K. Ellitsgaard-Rasmussen in 1952, the geology of the Fiskenæsset region was largely unknown until the writers' recent investigations. The chromite was found by the second writer (B. F.W.) during mapping the anorthosite-pyribolite complex in the summer of 1964 as part of the current mapping programme of the Geological Survey of Greenland (GGU). In the summers of 1965 and 1966 the first writer (M. G.) made an assessment of the distribution of chromite in the whole region and in 1966 undertook detailed mapping of the best chromite horizons.

In order to evaluate the possible economic potential of the deposits an analytical programme has been undertaken in Copenhagen by I. S $\phi$ rensen. $175 \mathrm{X}$-ray fluorescence analyses have been made, of which the 52 most reliable and representative of the region are presented in table IV. In addition, 14 partial and 4 complete chemical analyses (table II) have been made on selected samples. The main intention of the analytical work has been to determine the $\mathrm{Cr}-\mathrm{Fe}-\mathrm{V}$ oxides and the $\mathrm{Cr}: \mathrm{Fe}$ ratio of the chromite and the amount of chromite in the ore, and to find out if these values vary across the region.

The aim of this report is to present the field and laboratory results of GGU's investigation of the chromite in the Fiskenæsset region with a view to stimulating further economic interest in the deposits.

\section{THE ANORTHOSITE-PYRIBOLITE COMPLEX}

In the hypersthene gneisses and retrograde hornblende-biotite gneisses of the Fiskenæsset region there are stratigraphic horizons belonging to a folded and metamorphosed igneous complex (map 1). A brief description of the complex will be given as a background to the chromite deposits. 
1) Description of the components

The rocks constituting the complex can be divided into four groups: a) Anorthosites

Anorthosite is used as a group term to describe anorthositic rocks which are variable in structure and composition and which are the principal rocks of the complex. The plagioclase, a calcic bytownite-anorthite varying between $\mathrm{An}_{80}$ and $\mathrm{An}_{95}$, forms in some localities porphyroblastic aggregates oriented oblique to the chromite layering or in the axial planes of minor folds showing that they are of metamorphic origin and thus the main rock is more correctly a meta-anorthosite.

Anorthosite sensu stricto with more than $90 \%$ plagioclase is common and usually homogeneous, i. e. has no preferred orientation, as for example the anorthosite which encloses the boudinaged chromite horizons on Mánisât and Qeqertarssuatsiaq.

The anorthositic rocks commonly have between $70 \%$ and $95 \%$ plagioclase, the mafic minerals being hornblende, hypersthene, diopside, biotite and garnet. Where they are homogeneous, those with more than $10 \%$ mafic minerals may be termed gabbroic anorthosites, but there are many layered types consisting of alternating layers of pure and mafic anorthosite which range from a few millimetres to several tens of centimetres in width.

\section{b) Pyribolites}

With the increase in the amount of mafic minerals anorthositic rocks pass into pyribolites which are essentially hornblende-pyroxene-plagioclase rocks (for the original definition see Berthelsen, 1960, pp. 20-21) which could equally well be called hypersthene amphibolites or mafic granulites. They are layered rocks, individual layers expressing variation in the amounts of hypersthene, diopside, garnet, hornblende and plagioclase and they form the chief basic component of the complex. With increase in the amount of pyroxene at the expense of the remaining minerals some layers pass into pyroxenites. The assemblage plagioclase-hornblende-hypersthene is probably the most common, but these minerals vary considerably in their proportions. Garnet and diopside occur locally, giving rise to the assemblage plagioclasediopside-garnet-hornblende in a major basic horizon on SE Mánisât. Chromite 
has not been found in the pyribolites, although it may occur as it is obviously difficult in the field to detect black chromite layers in the dark pyribolite.

\section{c) Ultramafic rocks}

Ultramafic rocks form a subsidiary group within the complex, occurring as discontinuous layers and inclusions, usually between $30 \mathrm{~cm}$ and $20 \mathrm{~m}$ wide, in and between anorthosite and pyribolite horizons. Most commonly they have mineral assemblages formed by various combinations of olivine, diopside, bronzite, hornblende, garnet, spinel and magnetite. In addition two chromite-layered bronzitites have been found in the anorthosites. Although some of the rocks can be termed dunites, pyroxenites and peridotites, there are many with unusual combinations of minerals. For example, there are narrow layers in the pyribolite horizon just south of Kangârssuk with the following assemblages:

quartz-garnet-hornblende

hornblende-olivine-bronzite-spinel

hornblende-olivine-diopside-calcite-magnetite,

and in the narrow ultramafic layers on north Qeqertaq there are:

diopside-bronzite-hornblende-biotite

olivine-bronzite-hornblende-spinel

hornblende-bronzite-spinel.

There are many more assemblages in the ultramafic rocks, but a detailed description of these is beyond the scope of this report.

Sapphirine-corundum-bearing rocks form a distinctive but local feature occurring as layers and inclusions associated with the anorthosites. Besides that in Fiskenæsset harbour several new localities have been found in which the host rock contains most of the following minerals: sapphirine, corundum, spinel, gedrite, phlogopite, anorthite, bronzite, hornblende, muscovite, chlorite, carbonate, garnet and cordierite (for a petrographic description of the Fiskenæsset occurrence, see Sфrensen, 1955).

Some magnetite-layered pyroxenites and peridotites, forming layers and lenses up to about $5 \mathrm{~m}$ wide in the anorthosites, have high vanadium oxide contents ranging between $0.1 \%$ and $0.4 \%$.

d) Chromite horizons

These form the most important group in the complex economically 
and will be given a detailed, separate description. The following definitions should be noted: Chromitite is used to define a rock in which chromite is dominant and which forms layers usually between 0.5 and $10 \mathrm{~cm}$ wide with a chromite-rutile-hornblende-biotite-plagioclase assemblage. These alternate with anorthositic layers of the same width and together they are grouped in chromite horizons which are usually between 0.5 and $3 \mathrm{~m}$ wide. The rock constituting the chromite horizons is termed chrome ore.

\section{2) Structure}

The main structure of the complex is represented by an intercalation of anorthosite and pyribolite horizons which occurs on all scales; most commonly horizons are between 100 and $200 \mathrm{~m}$ wide, whilst on the smallest scale there are 10-30 cm wide layers of one within the other. In places there are major ultramafic horizons, as along the east side of Qeqertarssuatsiaq island, but the ultramafic rocks mostly occur on a minor scale as layers and inclusions in the anorthosites and pyribolites. The complex as a whole forms stratigraphic horizons that are usually between $100 \mathrm{~m}$ and $1 \mathrm{~km}$ wide, although west of Tasiussa bay they reach up to $2 \mathrm{~km}(6000 \mathrm{ft})$ in width, which is the present maximum width of the complex.

Although there is more anorthosite than pyribolite in the complex as a whole, their proportions vary widely. In the central Qeqertarssuatsiaq and Taseq areas there is an approximate $1: 1$ ratio between the two rocks, in the Mánisât and Angnertussoq-Tasiussâ areas anorthosite predominates, but on Kangarssuk there is far more basic rock than anorthosite.

It is emphasized that all the horizons shown on the map are almost entirely exposed, as there is a negligible cover of Quaternary deposits in the region. The fact that the anorthosite horizons can be easily seen on the aerial photographs has helped considerably in their mapping, although on the higher ground of the region and particularly to the east they are seen only with difficulty. The reason why they are easily visible at low altitudes is that no grass or lichen grows upon them and so they contrast with the dark lichencovered gneisses; at higher altitudes, mostly above 500-600 m, no grass or lichen grows on the gneisses either so that they cannot be distinguished from the anorthosites on the aerial photographs.

It should be noted that on map 1 the complex has been designated as 
a single unit, as on the published scale it has been impossible to differentiate between the closely intercalated anorthosite and pyribolite horizons.

Structures resembling cross-bedding are found locally and there are convincing examples of grading in the layered anorthosites. Their association with the chromite- and magnetite-layered rocks suggests that they are original structures. There has been observed no overall gradation in the intercalation of the horizons from dominantly ultramafic, through pyribolite, to dominantly anorthosite.

\section{3) History}

The fact that the anorthosites of the Fiskenæsset region contain chromite horizons indicates that both they and the complex as a whole have an igneous origin (Windley, in press), belonging to a layered body of stratiform type. The presence of chromite layers in anorthosite and bronzitite can only be satisfactorily explained by a process of gravity differentiation. The basic component in the Fiskenæsset region is a pyribolite which is considered to have been the norite member of the original complex, whilst peridotites and dunites are minor but genetically important features. There is an obvious analogy with the chromite-layered anorthosites and bronzitites and interbanded norites of the critical zone of the Bushveld complex.

The anorthosite-pyribolite complex has been affected by two periods of regional metamorphism. The first was a granulite facies metamorphism; the anorthosites and pyribolites in Fiskenæsfjorden are situated in hypersthene gneisses and are cut by hypersthene-bearing pegmatites. To the south of Fiskenæsfjorden the horizons occur in hornblende-biotite gneisses which contain relic horizons and inclusions of hypersthene gneisses, the anorthosites and pyribolites here also containing hypersthene. It is clear that a second, amphibolite facies metamorphism enabled the gneisses to recrystallise almost completely whilst the anorthosites and pyribolites lagged behind in retrogression and so retained their ortho-pyroxene. In the Angnertussoq area the chromitite layers of the anorthosites have been locally downgraded under greenschist facies conditions so that they have the assemblage: chromite-chlorite-epidote(hornblende)-plagioclase.

There is much evidence to suggest that both regional metamorphisms caused essentially isochemical recrystallisations, which allowed the complex 
as a whole to be remarkably well preserved. However the present mineral composition and textures must be regarded as largely secondary, the chromite and its layering representing the principal primary features.

The complex has been deformed by three major phases of folding. The first isoclinal phase with axial traces striking in all azimuths is represented by the closure on the south coast of Mánisat. The second phase, which is also isoclinal, has a general easterly trend, varying from $\mathrm{NE}$ to $\mathrm{SE}$, and is seen in the major fold core around the east side of Qeqertarssuatsiaq. The third phase, which has N-S to NW trending axial planes, forms the open to tight folds on central Qeqertarssuatsiaq. The form of the complex has been modified by tectonic thinning and thickening and the chromite horizons have commonly been boudinaged (fig. 4) and disrupted. The folding has also given rise to the duplication of the chromite-bearing horizons at the present surface level. The horizons extending across Mánisat and Qeqertarssuatsiaq can be seen to belong to a single horizon that has been folded by the three phases of folding. There are triple eye-fold patterns on a minor scale in chromite-layered anorthosite on the coast below Angnertussoq mountain and the present distribution of the anorthosite-pyribolite horizons in the region as a whole (see map 1) can be seen to represent a large-scale triple-folded interference pattern.

There is a close similarity between the rocks described here and the chromite-layered anorthosites of the Sittampundi complex, Madras State, India, described by Subramaniam (1956). Both complexes occur as conformable horizons in gneisses, have undergone regional metamorphism, have plagioclases ranging from calcic bytownite to anorthite, have inclusions of sapphirine- and corundum-bearing rocks (Subramaniam, personal communication, has only recently reported the presence of sapphirine), and constituent chromites have similar compositions (table V). 


\section{ECONOMIC GEOLOGY}

1) General description of the chromite

Chromite has been found in two rocks: anorthosite and bronzitite. Chromite-bearing bronzitite has only been found at two localities, in each place as an horizon in the anorthosite, $30 \mathrm{~cm}$ and $50 \mathrm{~cm}$ in width respectively, with chromitite layers $2 \mathrm{~mm}-1 \mathrm{~cm}$ wide. The occurrences are interesting because of the associated sulphide mineralisation forming the paragenesis pyrrhotite-pentlandite-chalcopyrite. Although these two horizons are not of immediate economic interest they provide an encouragement to further investigations of the ultramafic horizons which may be both chromite- and sulphide-bearing.

Chromite of economic interest, however, occurs as horizons within the anorthosites of the region and its mapping and sampling has covered an area of $750 \mathrm{~km}^{2}$ in which the total length of anorthosite exposure is $125 \mathrm{~km}$. Chromite horizons with an average width of $0.5-3 \mathrm{~m}$ are found in most of the anorthosites, the mutual contacts being sharp, and can be followed discontinuously for several tens of kilometres. They have been affected by three periods of folding and in many places are disrupted and boudinaged on both a major and minor scale. Two types of chromite rock can be distinguished:

i) A layered type in which individual chromitite layers are mostly $0.5-2 \mathrm{~cm}$ wide, although they reach $7-10 \mathrm{~cm}$ in several places (fig. 1) and $1 \mathrm{~m}$ locally (fig. 2). The chromitite layers alternate with layers of anorthosite of comparable thickness, and boundaries between the two rock types are sharp. The chromitite consists of chromite, rutile, hornblende, biotite and plagioclase, and contains on average 60-80 weight per cent chromite.

ii) An augen type characterised by porphyroblastic aggregates of plagioclase of variable size but generally with a diameter between 0.5 and $2 \mathrm{~cm}$ (fig. 3). The groundmass between the porphyroblasts is composed of chromite, rutile, hornblende, biotite and plagioclase, the amount of chromite being the same as in the layered type. The augen usually lie with their longest axes parallel to the layering of the horizons; in a few localities they lie oblique to the layering or are oriented in the axial planes of minor folds. The augentype horizons are the more common throughout the region and are usually wider than those of the layered type, reaching a maximum width of about $20 \mathrm{~m}$. 


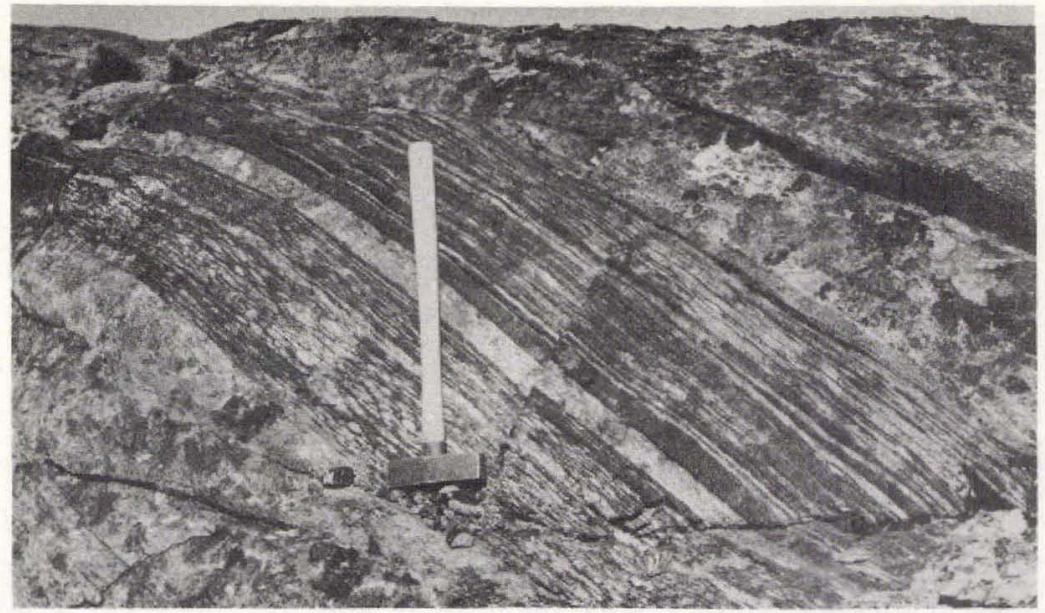

Fig. 1. Chromite horizon of mainly layered type with augen structure developed in the lower part. Hammer shaft $60 \mathrm{~cm}$ long.

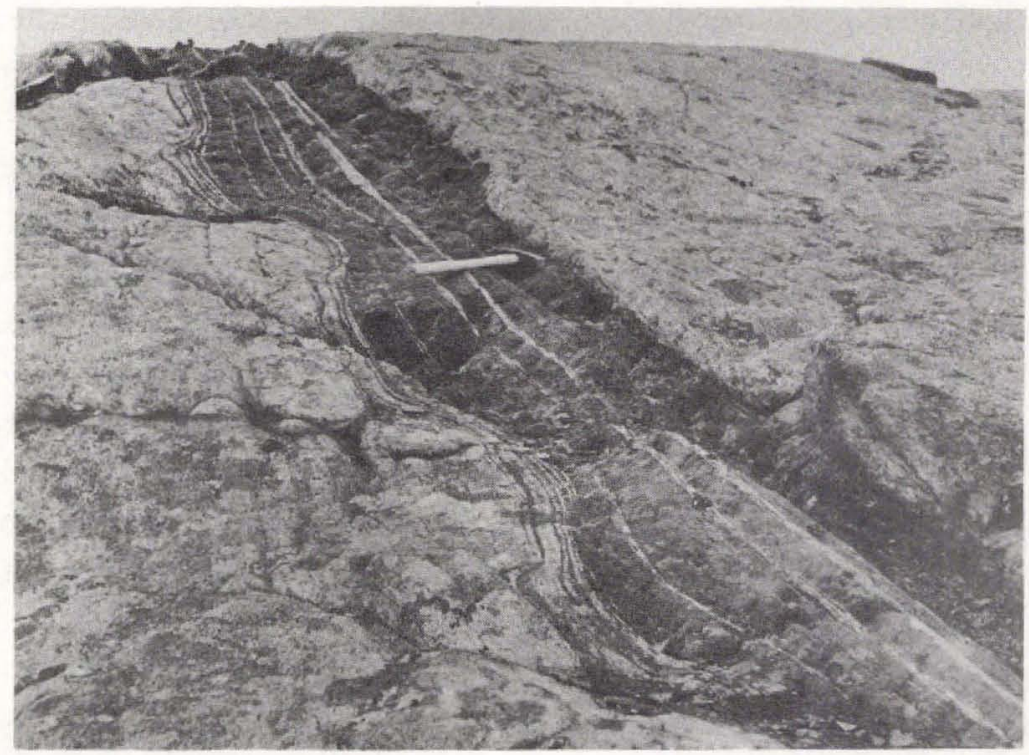

Fig. 2. Chromite horizon of layered type with thin intercalated anorthositic layers. 
It is quite common to find the two types of chromite rock close to each other (fig.1) and although a division has been made, in places there are gradations between the two seen as layered types containing porphyroblastic aggregates of plagioclase. From these intermediate types it is concluded that the augen structure developed by growth of plagioclase aggregates in the layered rocks.

In the following section the chromite-bearing anorthosite horizons are briefly described. They have been divided into four groups, the description following along the strike of each horizon. Where no mention of their orientation is made in the text or on the map the dip is approximately vertical.

2) The chromite-bearing anorthosite horizons

a) Lichtenfels-Fiskenæsset

This anorthosite horizon extends from the small islands south of Lichtenfels through Fiskenæsset and probably to the peninsula south-west of Qeqertaq in Fiskenæsfjorden. On the southern point of the peninsula to the south of Lichtenfels layers of anorthosite, intercalated with pyribolite, contain four $50 \mathrm{~cm}$ wide chromite horizons which can be followed for $200 \mathrm{~m}$ before thinning out. These chromite horizons are unusual in that each chromitite layer is only $1-2 \mathrm{~mm}$ in width. Nearer to Lichtenfels layered chromite horizons, $40-100 \mathrm{~cm}$ wide, are seen at a few localities, and immediately east of Lichtenfels two horizons, $50-100 \mathrm{~cm}$ in width, one of augen type and the other layered, can be followed for $300 \mathrm{~m}$ although they are dislocated many times by faults and pegmatites. Further to the north the anorthosite diverges, each branch containing fragments of chromite horizons which vary in width from $50 \mathrm{~cm}$ to $150 \mathrm{~cm}$. In the southern harbour at Fiskenæsset and on the islands to the west and east, $40-120 \mathrm{~cm}$ wide relics of both layered and augen types can be seen. Both types also occur on the peninsula south-west of Qeqertaq in horizons $50-100 \mathrm{~cm}$ in width but are never traceable for more than $50 \mathrm{~m}$.

b) Qeqertarssuatsiaq-Mánisât

The horizons seen on Qeqertarssuatsiaq and Mánisat islands belong to a single isoclinally folded anorthosite horizon which is the longest in the 


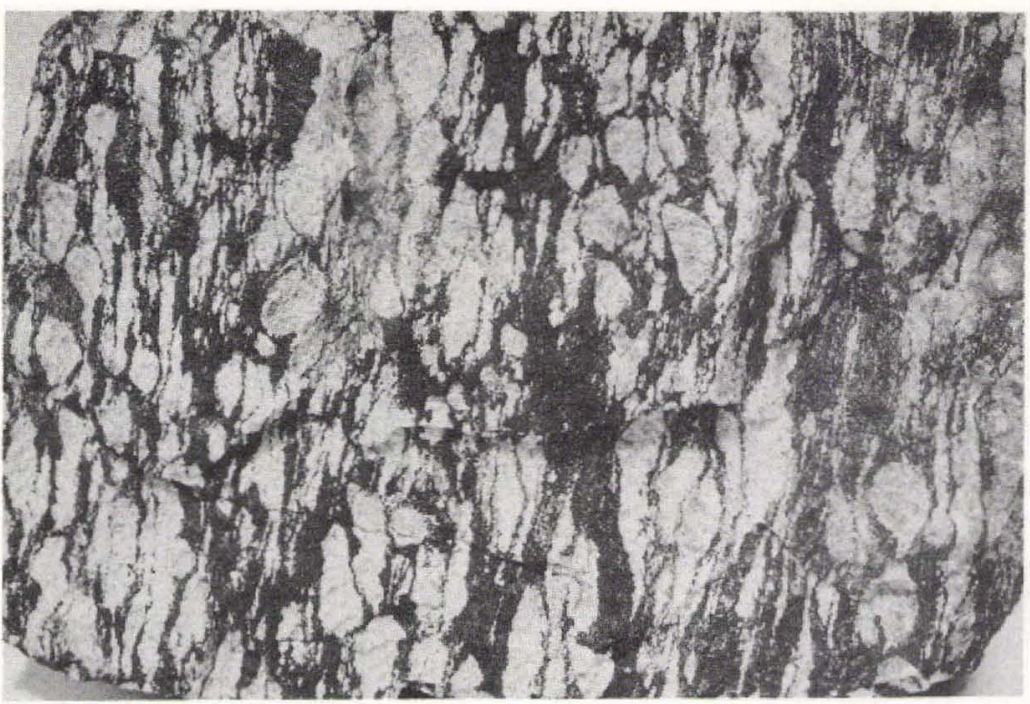

Fig. 3. Detail of an augen-type chromite horizon. The sample shown is $25 \mathrm{~cm}$ across.

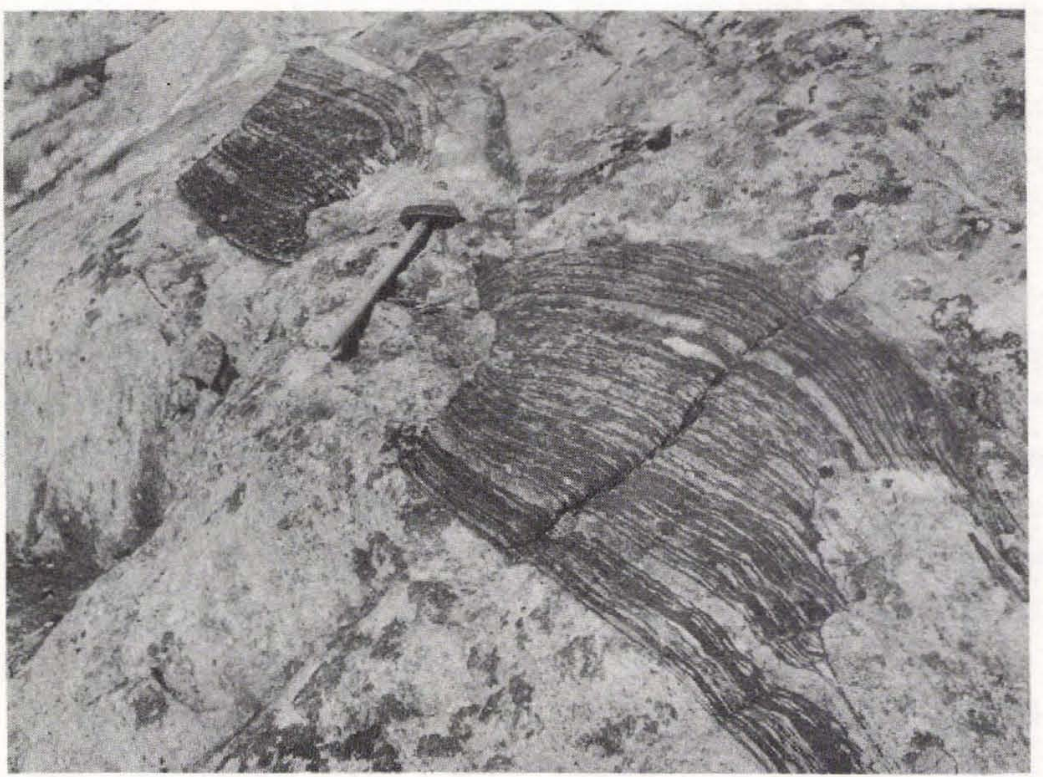

Fig. 4. Boudinaged relics of a layered-type chromite horizon. 
region, extending for $50 \mathrm{~km}$ on land. It passes from the north-eastern part of Qeqertarssuatsiaq to Mánisat, where it is folded back to the central part of Qeqertarssuatsiaq, and then along the east coast of the island to Fiskenæsfjorden.

In the northern limb on the central part of Qeqertarssuatsiaq a $1 \mathrm{~m}$ wide augen-type horizon can be followed for $200 \mathrm{~m}$, whilst in the major fold core there are at least two horizons of the same type, $2 \mathrm{~m}$ and $1 \mathrm{~m}$ wide, which are only traceable for a few tens of metres. It is at this locality that the $50 \mathrm{~cm}$ chromite-layered and sulphide-bearing bronzitite horizon is found. Between here and the island Nunaqarfinguaq only small relics of chromite horizons are seen, but on the island there are two horizons: a $2 \mathrm{~m}$ layered type and, to its east, a $50 \mathrm{~cm}$ augen type which are only continuous for about $10 \mathrm{~m}$. On the northern part of Mánisât there are a few relics of mainly layered type which are several metres long and $1 \mathrm{~m}$ wide, but on the southern part of the island several chromite horizons can be followed for about $1 \mathrm{~km}$. To the west there are three augen-type horizons, each averaging $1 \mathrm{~m}$ in thickness, which extend for $400 \mathrm{~m}$ north of the coast. East of these two layered-type horizons can be followed; in the south they average about $2 \mathrm{~m}$ in width but to the north they are only about $1 \mathrm{~m}$. All the horizons here dip $30^{\circ}-60^{\circ}$ to the east, are continuous for $50-100 \mathrm{~m}$, but are interrupted by $\mathrm{E}-\mathrm{W}$ striking faults.

The eastern limb on south-east Mánisat has two horizons of layered and one of augen type, varying from $50-200 \mathrm{~cm}$ in width, which can be followed discontinuously for $400 \mathrm{~m}$. A characteristic boudinage structure of a layered horizon is shown in fig. 4. In several places between the south and north coast of Mánisat there are small relics, $25-100 \mathrm{~cm}$ wide, of mainly layered type. No chromite has been found in the anorthosite between the west coast and the highest hill $(310 \mathrm{~m})$ on central Qeqertarssuatsiaq, although for $1400 \mathrm{~m}$ east of this hilltop there is a great deal of chromite in a horizon of mainly layered type (for a detailed map of this see map 2). This horizon averages $2 \mathrm{~m}$ in width, although in the western part it has a typical augen structure and reaches a maximum thickness of $10 \mathrm{~m}$. Further to the east there are only a few relic fragments of chromite horizons, and near the coast they are unimportant as they are strongly affected by folding, but there is here a malachite mineralisation associated with a N-S striking joint system. Along the east coast of Qeqertarssuatsiaq there is an important area, $1.5 \mathrm{~km}$ long (shown in map 3), where there are two horizons of augen 


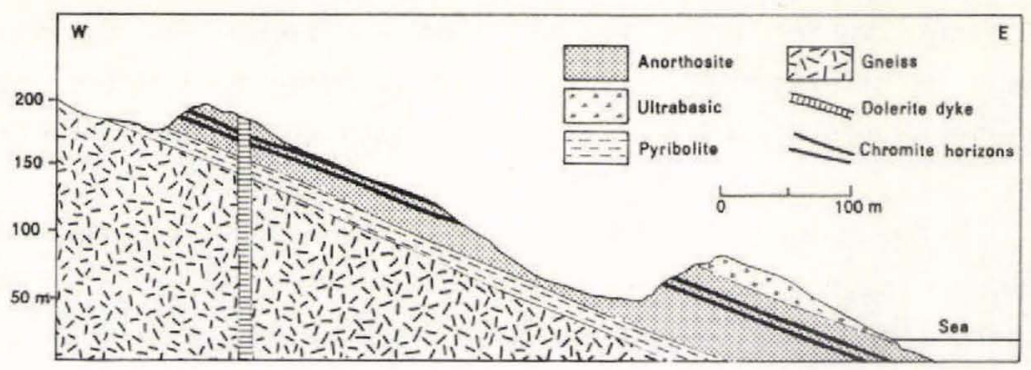

Fig. 5. Schematic section of the east coast of Qeqertarssuatsiaq.

type, the western averaging $2-5 \mathrm{~m}$ in width and the eastern $1 \mathrm{~m}$. They $\operatorname{dip} 20^{\circ}-40^{\circ}$ to the east, approximately parallel with the topography, as a result of which the chromite horizons in some places form the surface. Fig. 5 is a schematic section illustrating these relations. The chromite horizons can be followed for a further $1.5 \mathrm{~km}$ southwards along the coast, but they are not so continuous as in the area shown in map 3. At $200 \mathrm{~m}$ altitude on the north side of Fiskenæsfjorden the $30 \mathrm{~cm}$ wide chromitebearing bronzitite occurs in the major synformal fold core.

\section{c) Taseq}

This anorthosite horizon extends on both sides of Taseq, a large brackish lake, to the east of which there are only fragments of augen-type horizons, traceable for $200 \mathrm{~m}$ with a maximum width of $9 \mathrm{~m}$ and dipping $50^{\circ}$ to the north. To the west of Taseq a horizon of mainly augen type with an average width of $50-100 \mathrm{~cm}$ can be followed for $1 \mathrm{~km}$; but not continuously as it has been intensely folded. At several other places west of Taseq, e.g. in the bay south-east of Qeqertaq, chromite horizons of both augen and layered type can be traced for $200-300 \mathrm{~m}$ with average widths of $1-2 \mathrm{~m}$.

d) Kangârssuk-Angnertussoq-Tasiussâ

In the anorthosite horizons of Kangârssuk the chromite horizons are unimportant as the anorthosites occur mostly as fragments in a dominantly pegmatitic rock. The chromite relics, mainly of layered type, have an average width of only $20-50 \mathrm{~cm}$. Immediately to the east of Kangârssuk there are several chromite horizons of the same type and size. 


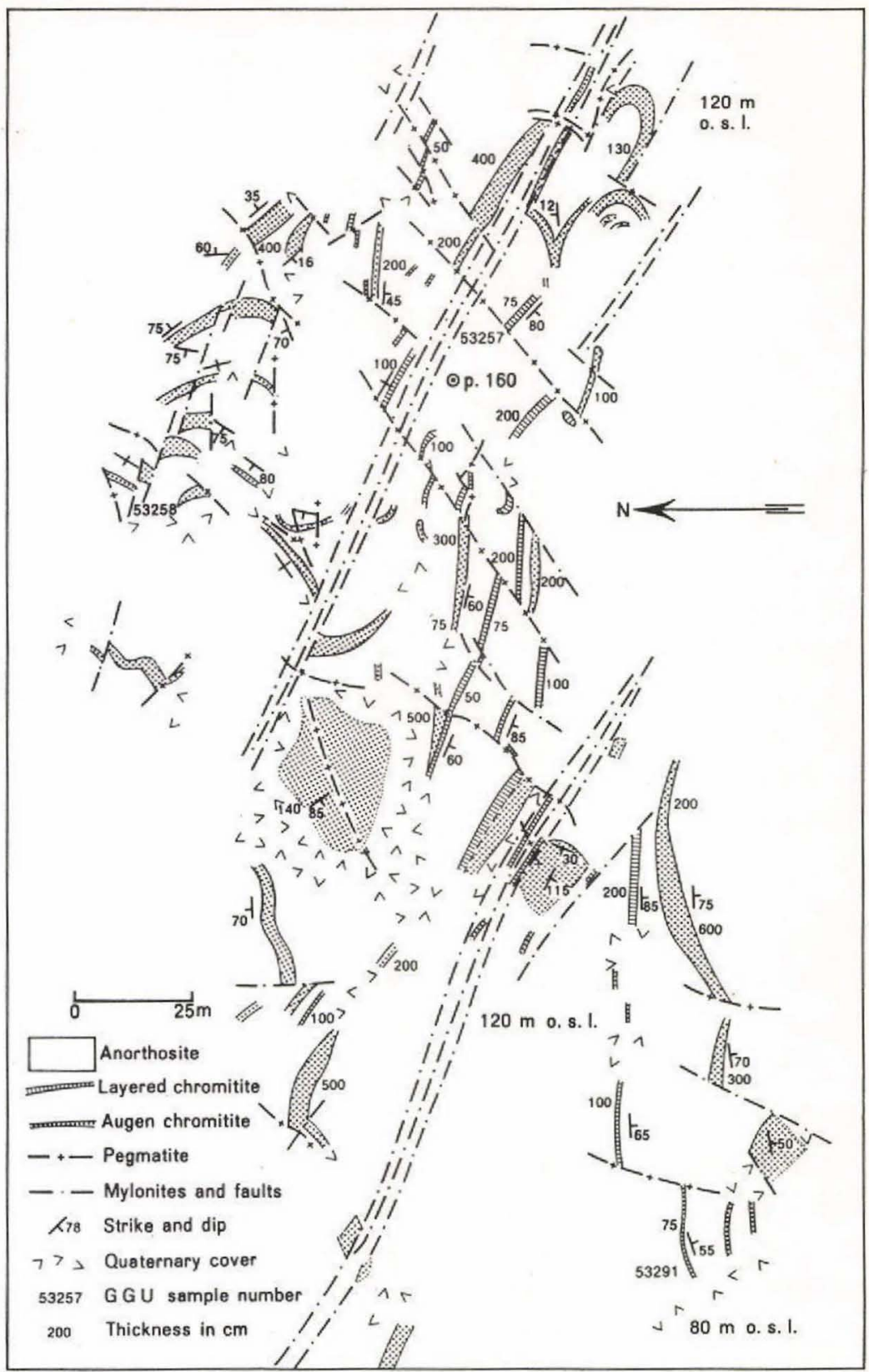

Fig. 6. Detailed map showing the complicated folded and faulted pattern of chromite horizons west of Tasiussa. 
At several places in the anorthosites extending from Angnertussoq to Tasiussa there are a number of chromite horizons of both types between $1 \mathrm{~m}$ and $2 \mathrm{~m}$ wide. Of special interest is the wide anorthosite horizon which extends from the west coast of Angnertussoq to the mountain Qagsse and further inland to the east. Where this horizon reaches its maximum width of $2 \mathrm{~km}$, west of Tasiussa, there is a complicated pattern of many folded and dislocated chromite horizons of both types, a detailed map of which is given in fig. 6. The westward continuation of one of these augen-type chromite horizons reaches a maximum width of $20 \mathrm{~m}$, whilst the average width of this vertical horizon is $5 \mathrm{~m}$ over a distance of $200 \mathrm{~m}$.

At a height of $600-700 \mathrm{~m}$ in the fold core south-west of Qagsse a wide folded chromite horizon of the layered type can be followed for several hundred metres. It dips $60^{\circ}$ to the south-west, varies in width from 1-3 m, reaching a maximum of $20 \mathrm{~m}$, and contains chromitite layers up to $1 \mathrm{~m}$ wide. This horizon probably continues to the east, but time did not allow investigation further inland. The southern limb of this anorthosite horizon has relics of chromitite layers in many places but they are intensely folded and discontinuous.

\section{3) Ore microscopy}

A brief ore microscopic study has been made on selected material from representative localities of economic interest, the ore minerals being studied in both the anorthosites and the bronzitites.

\section{a) Chromite in anorthosite}

Under the ore microscope the chromitites show variation in grain size, fracturing of grains, occurrence of alteration or exsolution products in the chromite, and the presence of other minerals. The silicate matrix consists mainly of hornblende and biotite and the individual chromitite layers are separated by anorthitic plagioclase layers or porphyroblasts which usually are free of chromite.

The chromitite is dominated by chromite, the grain size of which. averages between $0.25 \mathrm{~mm}$ and $0.50 \mathrm{~mm}$ in different samples, the ore grains forming elongate aggregates 2 - $5 \mathrm{~mm}$ long parallel to the layering. 
The grains are generally rounded at the corners, although they otherwise are hypidiomorphic; inclusions of silicate minerals are common. Cataclastic fracturing of the grains has not been observed except in one sample (78635) taken from a fault zone. The chromite shows very few or no internal reflexes which, according to Ramdohr (1960), is common in Fe-rich chromites, and it is unusual in being harder than both rutile and ilmenite.

In the ore mineral assemblage rutile is the most common associated mineral in nearly all polished sections. It occurs as rounded to elongate grains up to $1.5 \mathrm{~mm}$ in size, interstitial to chromite grains, as well as inclusions in and along grain boundaries of chromites. A special texture is a cubic network of rutile, forming needles $0.015-0.03 \mathrm{~mm}$ in length within chromite which may indicate an origin by alteration of ilmenite. The rutile shows very strong internal reflexes, most commonly with reddish-brown colours, but sometimes with yellow-brown varieties, which can be seen even in air and without crossed nicols. Twin-lamellae in all directions are common.

In a few samples ilmenite is associated with the rutile, the latter being predominant. In one sample (78502) the two minerals consistently occur together and all stages of alteration from ilmenite to rutile can be observed. Inclusions of ilmenite needles in the chromite forming a cubic network similar to that mentioned above for rutile indicate that at least part of the rutile in the chromite has formed by alteration from ilmenite.

Another associated ore mineral which is common in a few samples is magnetite, occurring as drop-like inclusions within the chromite, the size of which varies from a few $\mu$ to $0.015 \mathrm{~mm}$. In one sample (78578) magnetite with lamellae of chromite oriented in three directions can also be seen in larger areas along chromite grain boundaries. In the largest 'drops ' the same relation is found between the magnetite host and chromite lamellae. According to Ramdohr (op. cit.) both textures may be regarded as a result of exsolution. Haematite possibly occurs on a small scale along cracks in the magnetite and there may also be rutile as an alteration product of ilmenite. However, a detailed study is necessary to establish the relations between the different minerals in this complicated small-scale texture.

A few small grains of sulphide can be seen in nearly all sections and in one sample (78635) some pyrite grains $(0.05 \mathrm{~mm})$ were found with inclusions of chalcopyrite, surrounded by concentric layers of sphalerite. 
A lot of malachite can be seen as an alteration product throughout the whole rock and tenorite occurs in a few grains. The sulphide mineralisation in this sample can be correlated with the tectonic activity which gave rise to a set of N-S-striking faults.

The sulphide grains generally occur within the leucocratic parts of the rock, but in places may form inclusions in the chromite.

b) Chromite and sulphides in bronzitite

Chromite occurs in $2 \mathrm{~mm}-1 \mathrm{~cm}$ wide chromitite layers in bronzitite. The grain size and texture of the chromite resemble those described in the anorthosite, magnetite similarly being found as exsolution-drops in the chromite. Inmenite has been observed, but in only a few grains. Of particular interest is a late sulphide mineralisation (53218) which is seen in cracks and along grain boundaries between the minerals of the chromitite, the sulphide grains varying in size with an average width of $1.0 \mathrm{~mm}$ and forming aggregates up to $7 \mathrm{~mm}$. The predominant mineral is pyrrhotite, but a close subsidiary is pentlandite which occurs as elongate flamelike segregations within pyrrhotite and as rather large idiomorphic grains. Chalcopyrite is common and has been observed in a myrmekitic intergrowth with pyrrhotite. The pentlandite has been altered along cracks and grain boundaries to bravoite, which in this sample is a violet mineral with a reflectivity between pyrrhotite and chalcopyrite and a hardness higher than pentlandite but lower than pyrrhotite.

4) Petrology of the chromite-bearing rocks

The chromite has a bluish-black lustre and dark brown streak in the three types of chromitites (layered type, augen type, bronzitite) which in general contain between $60 \%$ and $80 \%$ chromite. Modal analyses of a number of chromite-bearing specimens are given in table I, for which 1000-1500 points have been counted. These are shown in order to demonstrate the range and variety of mineral compositions, thus samples with variable amounts of chromite have been selected.

a) Layered type

Chromitite layers, which are between a few millimetres and 
$1 \mathrm{~m}$ wide, are the mafic layers of the chromite horizons. In thin section it can be seen that the chromite is confined to these layers whilst the intervening layers consist solely of plagioclase (calcic bytownite-anorthite) and only rarely contain a few scattered grains of chromite. The chromite grains are embedded in a matrix of hornblende and biotite, giving rise to a pseudo-poikilitic texture similar to that in the Sittampundi chromitites described by Subramaniam (1956, p. 361). The longest dimensions of hornblende and biotite $(1.0 \mathrm{~mm})$ lie approximately parallel to the layering, but in a few rocks they lie normal or oblique to it demonstrating their secondary origin. When chromite is subordinate to the remaining minerals (6-8 of table I) it occurs as single subhedral to euhedral grains commonly with rounded corners, but where it is predominant it is more anhedral commonly forming aggregates arranged parallel to the layering and formed by coalescence of the closely-packed grains. The anhedral form of the chromite has been partly caused by the recrystallisation of hornblende and biotite. Chromite grains are between 0.05 and $0.7 \mathrm{~mm}$ across and aggregates reach up to $0.5 \mathrm{~cm}$ long. In layers rich in chromite (1-3 of table I) chain-in-chain structure is imperfectly developed; chromite grains contain inclusions of silicates and rutile is a prominent subsidiary ( 1 and 2 of table I) as single grains (up to $1.5 \mathrm{~mm}$ ) as well as inclusions in chromite.

In the Angnertussoq area, where there has been a retrogressive greenschist facies metamorphism, chromite occurs in chlorite-epidote layers which contain relics of hornblende. Basal planes of chlorite grouped in felted aggregates lie parallel to the layering.

No pyroxene has been found in the chromitites. However, as there is considerable evidence of the derivation of hornblende from pyroxene in the mafic and ultramafic rocks of the complex it can be inferred that the hornblende-rich chromitite layers were originally rich in pyroxene.

\section{b) Augen type}

Plagioclase augen, which reach up to about $5 \mathrm{~cm}$ long and $2 \mathrm{~cm}$ wide, are spindle-shaped aggregates of numerous plagioclase grains, which range up to $0.4 \mathrm{~mm}$ in length and have an equilibrium fabric commonly with $120^{\circ}$ triple junctions between grain boundaries. The augen are essentially monomineralic except for a few scattered chromites and hornblendes. The chromite is concentrated in the mafic groundmass which is composed 
Table I

Modal Composition of some Chromite-bearing Rocks

$\begin{array}{lrrrrrrrr} & 1 & 2 & 3 & 4 & 5 & 6 & 7 & 8 \\ \text { Plagioclase } & - & 2 & 5 & - & 28 & 56 & 55 & 52 \\ \text { Bronzite } & - & - & - & 28 & - & - & - & - \\ \text { Hornblende } & 17 & 29 & 24 & 25 & 25 & 15 & 23 & 29 \\ \text { Biotite } & 7 & 1 & 8 & - & 1 & 2 & - & 2 \\ \text { Chromite } & 73 & 65 & 62 & 47 & 46 & 27 & 22 & 15 \\ \text { Rutile } & 3 & 3 & 1 & - & <1 & <1 & - & - \\ \text { Epidote } & - & - & - & - & - & - & - & 2\end{array}$

1. $785876 \mathrm{~cm}$ chromitite layer. W Taseq.

2. $532821 \mathrm{~m}$ chromitite layer. Qagsse mountain.

3. $686251.5 \mathrm{~cm}$ layer from an augen-type horizon. Fiskenæsset harbour.

4. $686931 \mathrm{~cm}$ chromitite layer in hornblende-bronzitite occurring as $30 \mathrm{~cm}$ horizon in anorthosite. N side Fiskenæsfjorden.

5. $685962 \mathrm{~cm}$ folded chromitite layer in anorthosite. E Kangârssuk.

6. 68688 Diffuse $2 \mathrm{~cm}$ layer from an augen-type horizon. Bay SE of Qeqertaq, S side Fiskenæsfjorden.

7. $685950.5 \mathrm{~cm}$ chromite-bearing layer in anorthosite. E Kangârssuk.

8. 68718 Diffuse chromite-bearing layer in anorthosite. Lower Angnertussoq.

of this mineral, hornblende and biotite with a texture similar to that in the layered type.

The augen are in places oriented oblique to the layering and chromite is commonly compacted together between the augen. In rocks transitional between the layered and augen types it can be seen that the augen have deformed the original layering. 
c) Bronzitite

The rock consists of $2 \mathrm{~mm}-1 \mathrm{~cm}$ wide layers of chromitebronzite-hornblende (analysis 4, table I) which alternate with layers of bronzite-hornblende. Chromite grains range up to $0.7 \mathrm{~mm}$ across and mafics up to $3.0 \mathrm{~mm}$. The chromite is distributed as scattered subhedral to euhedral grains with rounded corners in the mafic groundmass and where compacted together forms elongate aggregates aligned parallel to the layering, the texture of the rock being similar to that of the layered type. In places strained pyroxenes are cut and surrounded by strain-free hornblendes suggesting that at least some of the hornblende is of retrogressive origin.

5) The analytical programme

a) Methods

All samples were collected from as fresh a surface as possible. A representative handspecimen was taken at each locality together with specimens of special interest, such as layers particularly rich in chromite. A slice, about $1-2 \mathrm{~cm}$ thick, was cut from each sample perpendicular to the layering. The representative material was used to obtain an impression of the chromite content of the ore and for the general analytical work.

The chromite was separated from the ore in as pure a state as possible. The specimens crushed to a grain size of $0.15-0.075 \mathrm{~mm}$ (100 - $200 \mathrm{mesh})$; those for chemical analysis were run once through a micropanner ${ }^{1)}$, the heavy mineral fraction obtained being cleaned twice with different current intensities by a Frantz magnetic separator ${ }^{2)}$.

For the X-ray fluorescence determinations the chromite was separated from the ore by only one run with the Frantz magnetic separator, the chromite fraction thus obtained being regarded as clean enough for this purpose.

1) L.D. Muller's micropanner

2) Isodynamic separator model L 1 
Chemical and spectrographic analyses: A few samples of separated chromite were chemically analysed for $\mathrm{Cr}_{2} \mathrm{O}_{3}$, total iron as $\mathrm{Fe}_{2} \mathrm{O}_{3}, \mathrm{Al}_{2} \mathrm{O}_{3}, \mathrm{Mg0}$, etc. in order to classify the chromite. $\mathrm{Cr}_{2} \mathrm{O}_{3}$ was determined potentiometrically after sodium peroxide fusion, and determination of the remaining oxides was made according to the standard procedure in the GGU laboratories (Borgen, in press). A few samples were analysed spectrographically for trace elements. The results are presented in tables II and III, percentages being given in weight per cent.

$\mathrm{X}$-ray fluorescence analyses: 175 samples of separated chromite were analysed for the components $\mathrm{Cr}_{2}{ }^{0} 3$, total iron and $\mathrm{V}_{2}{ }_{5}$. In order to standardise the analyses two international chromite standards ${ }^{1)}$ and ten chemically analysed chromite fractions from the present material were used $^{2}$ ? The object of the programme was to obtain an impression of the $\mathrm{Cr}, \mathrm{Fe}$ and $\mathrm{V}$ content of the chromites and the variation of the $\mathrm{Cr}: \mathrm{Fe}$ ratio in the area investigated. This method was suitable for the present investigation where a great quantity of homogeneous material had to be analysed as quickly as possible but with no need for a high degree of accuracy. The 52 representative analyses presented in table IV are arranged in four groups corresponding to the grouping of the horizons described in Section III 2.

1) Nat. Bureau of Stand. No. 103a and British Chem. Stand. No. 308

2) The $\mathrm{V}_{2} \mathrm{O}_{5}$ determinations were based on two samples: Nat. Bureau of Stand. No. $103 a$ and GGU No. 53225 . 
b) Analyses

Table II

Chemical Analyses of Chromites (Weight \%)

$\begin{array}{llll}1 & 2 & 3 & 4\end{array}$

\begin{tabular}{|c|c|c|c|c|}
\hline $\mathrm{Cr}_{2} \mathrm{O}_{3}+\mathrm{V}_{2} \mathrm{O}_{5}$ & 34.75 & 37.71 & 33.90 & 28.21 \\
\hline $\mathrm{Al}_{2} \mathrm{O}_{3}$ & 24.02 & 18.67 & 22.01 & 24.64 \\
\hline $\mathrm{Fe}_{2} \mathrm{O}_{3} \underset{\left(\mathrm{Fe}_{2} \mathrm{O}_{3}\right)}{(\mathrm{FeO})}$ & $\begin{array}{l}25.2334 .49 \\
\quad 6.48\end{array}$ & $\begin{array}{l}26.62 \\
9.16\end{array}$ & $\begin{array}{l}26.9639 .31 \\
9.38\end{array}$ & $\begin{array}{l}23.7138 .53 \\
12.21\end{array}$ \\
\hline $\mathrm{MgO}$ & 6.20 & 4. 76 & 4.94 & 7.01 \\
\hline $\mathrm{SiO}_{2}$ & 0.76 & 0.33 & 0.58 & 0.93 \\
\hline $\mathrm{TiO}_{2}$ & 0.44 & 0.56 & 0.56 & 0.58 \\
\hline $\mathrm{MnO}$ & 0.28 & 0.35 & 0.00 & 0.30 \\
\hline $\mathrm{CaO}$ & 0.00 & 0.00 & 0.00 & 0.00 \\
\hline $\mathrm{Na}_{2} \mathrm{O}$ & 0.07 & 0.09 & 0.15 & 0.25 \\
\hline $\mathrm{K}_{2} \mathrm{O}$ & 0.15 & 0.17 & 0.15 & 0.35 \\
\hline $\mathrm{P}_{2} \mathrm{O}_{5}$ & 0.10 & 0.15 & 0.18 & 0.15 \\
\hline & 98.48 & 98.57 & 98.81 & 98.34 \\
\hline $\mathrm{Cr}: \mathrm{Fe}$ & 0.99 & 0.95 & 0.84 & 0.72 \\
\hline
\end{tabular}

For notes on samples see p. 24. 
Table III

Spectrographic Analyses of Chromites* (Weight \%)

1

$\mathrm{V}$

$\left(\mathrm{V}_{2} \mathrm{O}_{5}\right)$

Co

$\mathrm{Ni}$

$\mathrm{Pt}$

* by H. Bollingberg
3

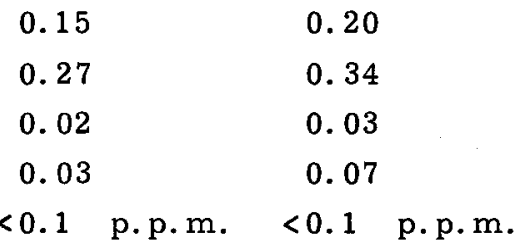

$<0.1$ p.p.m. <0.1 p.p.m.

1. 53282 Chromite from $1 \mathrm{~m}$ chromitite layer.

Qagsse mountain.

2. 78587 Chromite from $6 \mathrm{~cm}$ chromitite layer. Taseq.

3. 53225 Chromite from $4.5 \mathrm{~m}$ augen-type horizon. East Qeqertarssuatsiaq.

4. 53218 Chromite from 2-4 $\mathrm{mm}$ chromitite layers within a $50 \mathrm{~cm}$ bronzitite. Qeqertarssuatsiaq. 
Table IV

X-Ray Fluorescence Analyses of Chromites (Weight \%)

\begin{tabular}{rcrrrrr}
$\begin{array}{c}\text { Specimen } \\
\text { No. }\end{array}$ & $\begin{array}{l}\text { Chromite } \\
\text { in ore }\end{array}$ & $\mathrm{Cr}_{2} \mathrm{O}_{3}$ & $\mathrm{FeO}^{*}$ & $\mathrm{~V}_{2} \mathrm{O}_{5}$ & $\mathrm{Cr}: \mathrm{Fe}$ & $\begin{array}{r}\mathrm{Cr}_{2} \mathrm{O}_{3} \\
\text { in }^{2}\end{array}$ \\
\hline \multicolumn{7}{c}{ The Lichtenfels } \\
$7_{78445^{\mathrm{b}}}$ & 29.7 & 30.1 & 40.6 & 0.50 & 0.66 & 8.9 \\
$78452^{\mathrm{b}}$ & 31.8 & 32.0 & 35.4 & 0.32 & 0.80 & 10.2 \\
$78489^{\mathrm{b}}$ & 45.0 & 31.4 & 36.2 & 0.30 & 0.77 & 14.1 \\
$78402^{\mathrm{b}}$ & 21.6 & 33.9 & 31.0 & 0.27 & 0.96 & 7.3 \\
$78483^{\mathrm{b}}$ & 33.0 & 33.4 & 30.6 & 0.26 & 0.96 & 11.0 \\
$78438^{\mathrm{b}}$ & 48.7 & 33.4 & 31.4 & 0.28 & 0.94 & 16.2 \\
$78404^{\mathrm{b}}$ & 39.9 & 32.9 & 29.0 & 0.29 & 1.00 & 13.1 \\
$78439^{\mathrm{b}}$ & 46.3 & 33.2 & 30.8 & 0.29 & 0.95 & 15.4 \\
$78524^{\mathrm{b}}$ & 29.2 & 33.8 & 29.6 & 0.28 & 1.01 & 9.9 \\
$78517^{\mathrm{a}}$ & 39.2 & 32.8 & 32.8 & 0.34 & 0.88 & 12.8
\end{tabular}

The Qeqertarssuatsiaq - Mánisât Horizon

$\begin{array}{llllllr}78601^{\mathrm{a}} & 53.2 & 34.1 & 32.1 & 0.33 & 0.94 & 18.2 \\ 78543^{\mathrm{a}} & 48.1 & 31.8 & 29.6 & 0.27 & 0.95 & 15.3 \\ 78598^{\mathrm{a}} & 45.1 & 34.2 & 30.2 & 0.32 & 1.01 & 15.4 \\ 78546^{\mathrm{a}} & 45.1 & 31.5 & 33.6 & 0.28 & 0.80 & 14.2 \\ 78548^{\mathrm{a}} & 36.5 & 29.9 & 35.2 & 0.24 & 0.75 & 10.9 \\ 78499^{\mathrm{b}} & 35.0 & 26.2 & 33.4 & 0.28 & 0.70 & 9.2 \\ 78504^{\mathrm{a}} & 35.0 & 30.4 & 32.2 & 0.31 & 0.85 & 10.6 \\ 78430^{\mathrm{b}} & 39.1 & 33.1 & 34.4 & 0.39 & 0.85 & 12.9 \\ 78480^{\mathrm{b}} & 48.0 & 34.8 & 32.4 & 0.30 & 0.95 & 16.7 \\ 78470^{\mathrm{b}} & 17.5 & 26.3 & 37.8 & 0.47 & 0.61 & 4.6 \\ 78472^{\mathrm{b}} & 42.4 & 34.3 & 33.6 & 0.28 & 0.91 & 14.2 \\ 78508^{\mathrm{a}} & 50.0 & 33.4 & 33.6 & 0.34 & 0.88 & 16.7 \\ 78464^{\mathrm{b}} & 35.9 & 34.2 & 29.2 & 0.32 & 1.03 & 12.3 \\ 78420^{\mathrm{b}} & 41.0 & 32.6 & 31.0 & 0.28 & 0.93 & 13.4 \\ 78424^{\mathrm{b}} & 44.4 & 33.4 & 29.0 & 0.27 & 1.01 & 14.8\end{array}$

* Total iron calculated as FeO 
Table IV (continued)

\begin{tabular}{ccccccc}
$\begin{array}{c}\text { Specimen } \\
\text { No. }\end{array}$ & $\begin{array}{l}\text { Chromite } \\
\text { in ore }\end{array}$ & $\mathrm{Cr}_{2} \mathrm{O}_{3}$ & $\mathrm{FeO}$ & $\mathrm{V}_{2} \mathrm{O}_{5}$ & $\mathrm{Cr}: \mathrm{Fe}$ & $\begin{array}{c}\mathrm{Cr}_{2} \mathrm{O}_{3} \\
\text { in ore }\end{array}$ \\
\hline $78639^{\mathrm{c}}$ & 71.1 & 31.2 & 32.6 & 0.29 & 0.85 & 22.2 \\
$78640^{\mathrm{c}}$ & 68.8 & 31.2 & 29.6 & 0.28 & 0.94 & 21.5 \\
$78577^{\mathrm{a}}$ & 45.8 & 31.4 & 34.0 & 0.28 & 0.82 & 14.4 \\
$78582^{\mathrm{a}}$ & 45.3 & 32.9 & 31.0 & 0.27 & 0.94 & 14.9 \\
$78603^{\mathrm{a}}$ & 41.2 & 32.4 & 32.3 & 0.32 & 0.89 & 13.3 \\
$78608^{\mathrm{a}}$ & 50.4 & 33.0 & 30.4 & 0.28 & 0.96 & 15.0 \\
$78612^{\mathrm{a}}$ & 40.2 & 32.9 & 29.7 & 0.28 & 0.99 & 13.2 \\
$68693^{\mathrm{d}}$ & 30.0 & 32.4 & 29.0 & - & 0.99 & 9.7
\end{tabular}

The Taseq Horizon

$\begin{array}{lllllll}78529^{\mathrm{a}} & 49.5 & 30.8 & 28.8 & 0.25 & 0.95 & 15.2 \\ 78557^{\mathrm{a}} & 45.3 & 35.9 & 30.6 & 0.32 & 1.04 & 16.3 \\ 78573^{\mathrm{a}} & 36.6 & 36.1 & 33.8 & 0.35 & 0.95 & 13.2 \\ 78587^{\mathrm{c}} & 80.2 & 36.2 & 30.6 & 0.37 & 1.05 & 29.1 \\ 78566^{\mathrm{a}} & 54.5 & 35.2 & 33.6 & 0.34 & 0.93 & 19.2 \\ 78592^{\mathrm{c}} & 68.3 & 34.2 & 31.0 & 0.31 & 0.98 & 23.4 \\ 78594^{\mathrm{c}} & 69.8 & 33.9 & 30.4 & 0.30 & 1.01 & 23.6\end{array}$

The Kangârssuk and Angnertussoq - Tasiussâ Horizons

$\begin{array}{llllllr}78654^{\mathrm{b}} & 29.0 & 31.4 & 31.8 & 0.28 & 0.85 & 9.2 \\ 78655^{\mathrm{b}} & 23.2 & 31.0 & 31.4 & 0.27 & 0.88 & 7.2 \\ 78656^{\mathrm{b}} & 49.8 & 33.2 & 30.5 & 0.26 & 0.96 & 16.6 \\ 78681^{\mathrm{c}} & 63.6 & 33.8 & 31.4 & 0.28 & 0.96 & 21.3 \\ 78648^{\mathrm{b}} & 24.4 & 32.0 & 31.4 & 0.29 & 0.91 & 7.8 \\ 78691^{\mathrm{c}} & 62.0 & 32.3 & 30.7 & 0.28 & 0.93 & 20.0 \\ 78695^{\mathrm{c}} & 40.7 & 34.2 & 28.8 & 0.25 & 1.05 & 13.9 \\ 78677^{\mathrm{b}} & 34.1 & 30.8 & 29.4 & 0.25 & 0.93 & 10.5 \\ 78660^{\mathrm{b}} & 39.6 & 31.8 & 29.4 & 0.28 & 0.96 & 12.6 \\ 78658^{\mathrm{b}} & 61.4 & 31.2 & 29.7 & 0.26 & 0.93 & 19.2\end{array}$


Table IV (continued)

\begin{tabular}{llllllr}
$\begin{array}{c}\text { Specimen } \\
\text { No. }\end{array}$ & $\begin{array}{l}\text { Chromite } \\
\text { in ore }\end{array}$ & $\mathrm{Cr}_{2} \mathrm{O}_{3}$ & $\mathrm{FeO}$ & $\mathrm{V}_{2} \mathrm{O}_{5}$ & $\mathrm{Cr}: \mathrm{Fe}$ & $\begin{array}{l}\mathrm{Cr}_{2} \mathrm{O}_{3} \\
\text { in ore }\end{array}$ \\
\hline $78671^{\mathrm{a}}$ & 39.1 & 31.6 & 31.9 & 0.29 & 0.91 & 12.4 \\
$78674^{\mathrm{a}}$ & 26.4 & 33.4 & 31.9 & 0.27 & 0.93 & 8.8
\end{tabular}

a) Augen type (rock sample composed of chromitite matrix with plagioclase porphyroblasts).

b) Layered type (rock sample composed of alternating chromitite and anorthositic layers).

c) Chromitite (rock sample from a single chromitite layer).

d) Chromitite in bronzitite (rock sample with alternating layers of chromitite and bronzitite). 
c) Discussion of results

According to the $\mathrm{X}$-ray fluorescence analyses the $\mathrm{Cr}_{2} \mathrm{O}_{3}$ content of the chromite varies within the range $26 \%$ - $36 \%$ although the majority of analyses lie close to the average of $32.7 \%$. These are regarded as minimum values, as the separated chromite fractions were not perfectly clean and give $\mathrm{Cr}_{2} \mathrm{O}_{3}$ values a few percent lower than those derived by chemical analyses (e.g. 78587). There is no significant variation in chromite composition throughout the region.

The iron oxide content varies between $28 \%$ and $42 \%$ with an average of $31.8 \%$ (as $\mathrm{FeO}$ ). From the ore microscopic observations it is known that the highest $\mathrm{Fe}$ content can be expected to occur where magnetite is found as very small exsolved 'drops' within the chromite. In such samples even a refined separation method will not reduce the Fe content of the chromite fraction. The chromites investigated show quite a high susceptibility due to their richness in iron and this affects their magnetic separation.

The $\mathrm{Cr}: \mathrm{Fe}$ ratio varies between 0.66 and 1.05 with an average of 0.93 , the lowest ratios belonging to the samples with magnetite exsolutions in the chromite, and the remainder lying close to the value 0.93 .

The vanadium oxide content of the chromite is significantly high, varying between $0.24 \%$ and $0.50 \%$, but the values mostly lie near the average of $0.30 \%$. By plotting $\mathrm{FeO}$ (total iron) against $\mathrm{V}_{2} \mathrm{O}_{5}$ it is seen that the highest $\mathrm{V}$ contents roughly correspond to the highest $\mathrm{Fe}$ contents whilst the chromites low in iron are also low in vanadium (see fig. 7). Moreover some magnetites have a high $\mathrm{V}$ content.

The alumina content of the chromite is high, whereas the magnesia is low, in accordance with the high ferrous iron content. Only total iron as $\mathrm{Fe}_{2} \mathrm{O}_{3}$ was determined analytically, the $\mathrm{Fe}_{2} \mathrm{O}_{3}$ and $\mathrm{FeO}$ contents being calculated, on the assumption that the ratio of the RO: $\mathrm{R}_{2} \mathrm{O}_{3}$ components is equal to 1 . Manganese oxide amounts to less than $0.5 \%$, the manganese replacing the ferrous iron in the chromite lattice. According to observations on polished sections the presence of silica is due to rounded silicate inclusions in the chromite grains which were not separable from the analysed fraction. Titanium oxide amounts to less than $1 \%$ and is due to interstitial rutile (and ilmenite) which occur in fine-grained intergrowths and thus have not been separated from the chromite. The spectrographic analyses show a distinct platinum content slightly below 0.1 p.p.m. 


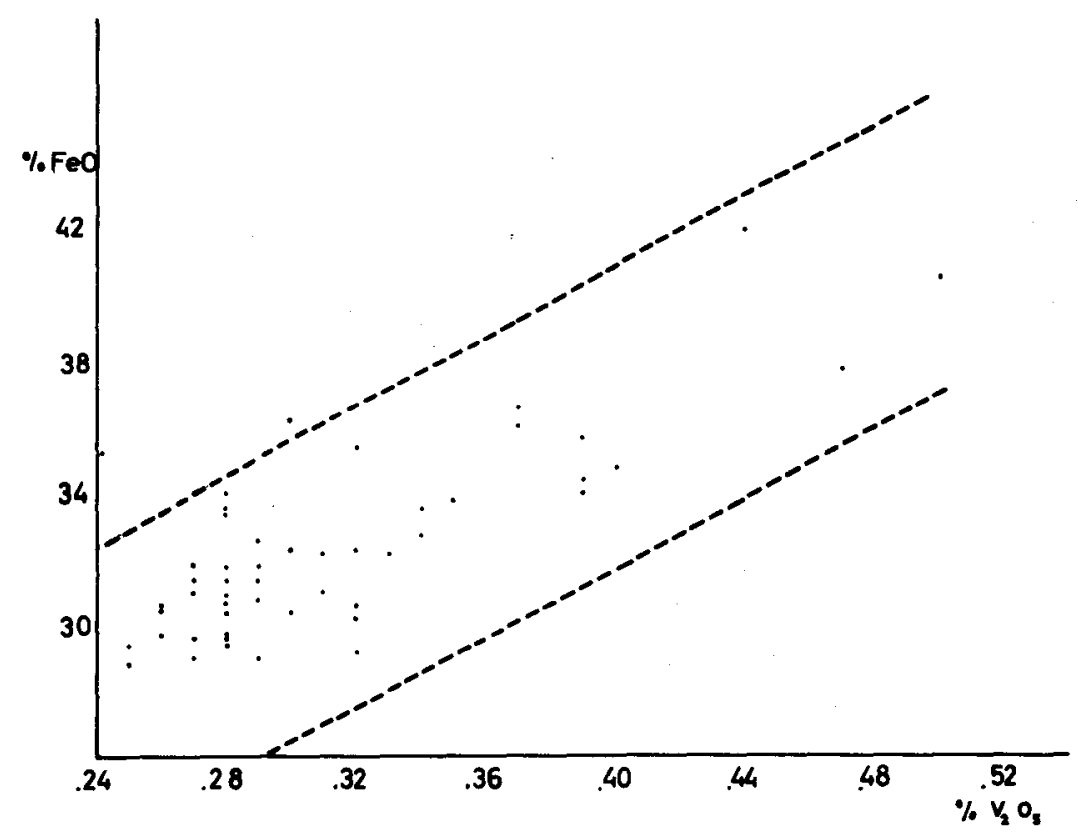

Fig. 7. Diagram showing the relationship between total iron as $\mathrm{FeO}$ and $\mathrm{V}_{2} \mathrm{O}_{5}$ in some representative chromites.

d) Classification of the chromite

Four complete analyses of Fiskenæsset chromites are given in table II, three being from chromite horizons in anorthosites and one from bronzitite. It can be seen that the chromites are rich in alumina and iron and low in magnesia. In order to illustrate the composition of the chromite, two diagrams (fig. 8) from Thayer (1956, pp. 16-17) have been used, representing the composition of the $\mathrm{RO}$ and $\mathrm{R}_{2} \mathrm{O}_{3}$ components. As the chromites have a high FeO: $\mathrm{MgO}$ ratio the plane of composition (RO) occurs in the lower part of fig. 8a, whilst the projected points of the $\mathrm{R}_{2} \mathrm{O}_{3}$ components $\left(\mathrm{Al}_{2} \mathrm{O}_{3}, \mathrm{Fe}_{2} \mathrm{O}_{3}, \mathrm{Cr}_{2} \mathrm{O}_{3}\right)$ on this plane (fig. 8b) show that the Fiskenæsset chromites fall in the field of aluminous chromite. 

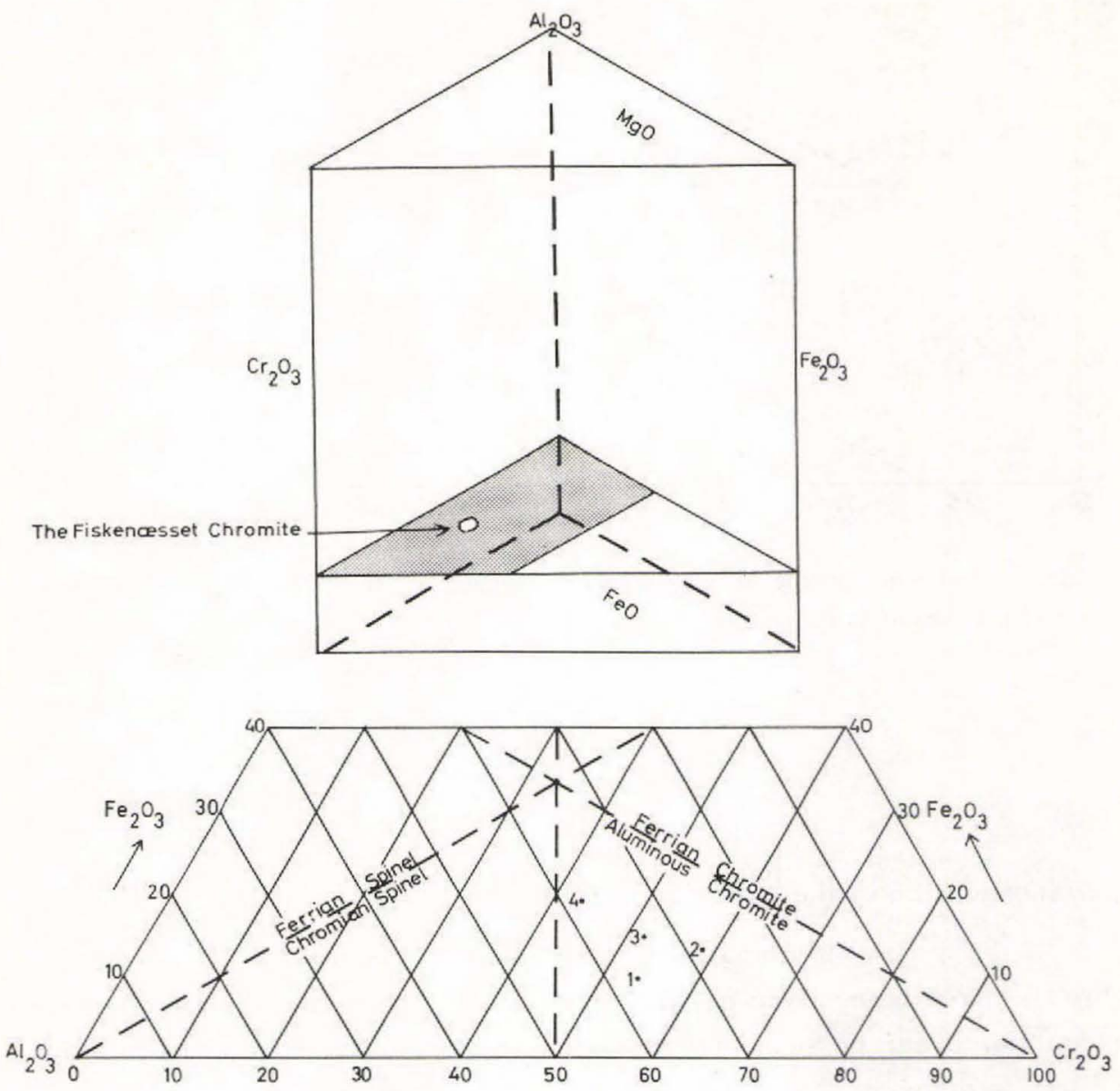

Fig. 8. Two diagrams illustrating the composition of the Fiskenæsset chromites. 
It should be remembered that part of the ferric iron content is probably due to the very small exsolved 'drops' of magnetite in the chromite, as revealed particularly by the ore microscopic study of specimen no. 53218 (analysis 4, table II) from the bronzitite. This largely accounts for the deviating position of this specimen in fig. $8 \mathrm{~b}$.

By omitting oxygen and the subscripts and by recalculating the RO and $\mathrm{R}_{2} \mathrm{O}_{3}$ constituents to $100 \%$ as done by Malhotra and Prasada Rao (1963, pp. 233-34) the formula of chromite can be written as follows:

$$
\left[\mathrm{Mg}_{\mathrm{a}} \mathrm{Fe}_{\mathrm{b}}^{\mathrm{II}} \mathrm{Mn}(100-\mathrm{a}-\mathrm{b})\right] \quad\left[\mathrm{Cr}_{\mathrm{x}} \mathrm{Al}_{\mathrm{y}} \mathrm{Fe} \mathrm{III}_{(100-\mathrm{x}-\mathrm{y})}\right]
$$

The formulae of the four analysed chromites are accordingly:

$$
\begin{array}{lccc}
\text { 1. } & 53282 & \left(\mathrm{Mg}_{28} \mathrm{Fe}_{71} \mathrm{Mn}_{1}\right) & \left(\mathrm{Cr}_{45} \mathrm{Al}_{47} \mathrm{Fe}_{8}\right) \\
\text { 2. } & 78587 & \left(\mathrm{Mg}_{23} \mathrm{Fe}_{76} \mathrm{Mn}_{1}\right) & \left(\mathrm{Cr}_{50} \mathrm{Al}_{38} \mathrm{Fe}_{12}\right) \\
\text { 3. } & 53225 & \left(\mathrm{Mg}_{23} \mathrm{Fe}_{77} \mathrm{Mn}\right) & \left(\mathrm{Cr}_{44} \mathrm{Al}_{44} \mathrm{Fe}_{12}\right) \\
\text { 4. } & 53218 & \left(\mathrm{Mg}_{34} \mathrm{Fe}_{65} \mathrm{Mn}_{1}\right) & \left(\mathrm{Cr}_{36} \mathrm{Al}_{49} \mathrm{Fe}_{15}\right)
\end{array}
$$

6) Economic potential

a) Grade of ore

The Fiskenæsset chrome ore is considered to be of low grade and a preliminary figure for its value can be obtained from the analytical programme. The separated and more or less pure chromite fractions were weighed and their ratios to the unseparated material calculated, the resulting percentages being listed as 'chromite in ore' in table IV. The standard deviation of the values is $s=12.9 \%$. Figure 9 shows the observed frequency distribution of the chromite content in ore for 164 samples together with the computed frequency distribution about the arithmetic mean of $41.9 \%$. Comparing these two, an approximately normal distribution can be seen with a symmetrical spread of values about the arithmetic mean. This shows that if the samples are accepted as representative of the chromite horizons of the region the mean value for the chromite content of the ore is $41.9 \pm 1.7 \%$ (the $90 \%$ confidence limits based on the 'students $t$ ' distribution). 


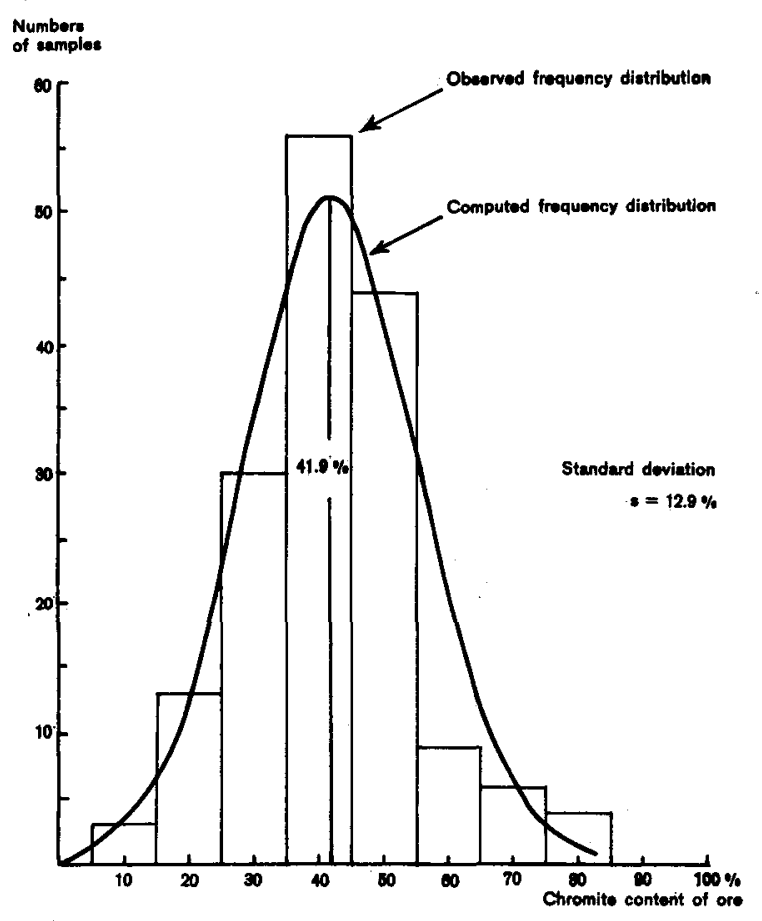

Fig. 9. Histogram showing the frequency distribution of the chromite content in the ore of 164 samples.

As the $\mathrm{Cr}_{2} \mathrm{O}_{3}$ content of the chromite is known, an average value for that of the ore (chromitite with intercalated plagioclase) may be calculated and is about $14 \%$. The chromitite component of the ore contains 60-80\% chromite and therefore 20-26\% $\mathrm{Cr}_{2} \mathrm{O}_{3}$.

For an economic valuation the high vanadium content is of particular interest. The maximum values of $\mathrm{V}_{2} \mathrm{O}_{5}(0.5 \%)$ are found in the chromite fractions rich in iron, whilst the average value $(0.30 \%)$ refers to the chromite as a whole throughout the region.

Traces of platinum in the chromite- and sulphide-bearing rocks should be further investigated. 
b) Amount of ore

At the present stage it is difficult to give an estimate of the quantity of ore as no drilling has been undertaken, but the general geology may give some information about the depth of continuation of the chromite horizons. These horizons are found at all altitudes between sea level and $800 \mathrm{~m}$ with no significant variations in their structure or composition. The nature of the complex - a steeply dipping stratiform body - suggests that chromite horizons continue at least to the maximum depth at which mining is practicable. There is, however, a special type of structural problem concerned with the extent of rupture and folding at the various localities. Before any particular body has been delineated it is of little value to estimate reserves of ore, but it is nevertheless thought worthwhile to discuss one example of particular interest taken from the area on the east coast of Qeqertarssuatsiaq, mapped on a scale $1: 1000$ and shown in map 3 .

The main chromite horizon along this coast varies between $1 \mathrm{~m}$ and $7 \mathrm{~m}$ in width, averaging $2.5 \mathrm{~m}$, and can be followed for about $1400 \mathrm{~m}$, the horizon being exposed for $20 \%$ of the distance along the strike. Its dip varies between $20^{\circ}$ and $40^{\circ}$ to the east and in places is parallel to the slope of the topography (see fig. 5), which means that there is a $200 \mathrm{~m}$ wide section of accessible horizons along this stretch of coast. The specific gravity of the ore, composed of chromite, hornblende, biotite, rutile and plagioclase, is calculated.as 3.65 from the separated rock components. This gives about 2.5. million tons of chrome ore containing 1 million tons of chromite or 350000 tons of $\mathrm{Cr}_{2} \mathrm{O}_{3}$ and 3000 tons of $\mathrm{V}_{2} \mathrm{O}_{5}$. This example is given only so that the reader has an idea of the scale of the chromite deposits and no attempt is made to discuss the economic and practical possibilities, such as open pit mining, at this locality. It should be remembered that the reserves calculated here are those in a $1400 \mathrm{~m}$ stretch of one chromite horizon, but as the anorthosite horizons can be followed for about $125 \mathrm{~km}$, nearly all containing chromite horizons of similar appearance, the total amount of chrome ore in the region must be considerable. Although no specific ore bodies have been defined, this description may give a general impression of the extent of ore reserves in the region. 
c) Comparison with other chrome ores

Table V

Chemical Composition of some Comparable Chromites (Weight \%)

$\begin{array}{lllll}1 & 2 & 3 & 4 & 5\end{array}$

\begin{tabular}{|c|c|c|c|c|c|}
\hline $\mathrm{Cr}_{2} \mathrm{O}_{3}$ & 34.48 & 42.76 & 36.88 & 38.26 & 45.7 \\
\hline $\mathrm{Al}_{2} \mathrm{O}_{3}$ & 24.02 & 23.85 & 24.12 & 30.30 & 15.0 \\
\hline $\mathrm{FeO}$ & 25.23 & $21.51 *$ & $29.40 *$ & 10.84 & 23.6 \\
\hline $\mathrm{Fe}_{2} \mathrm{O}_{3}$ & 6.48 & & & 2.55 & 5.5 \\
\hline $\mathrm{MgO}$ & 6.20 & 10.36 & 7.22 & 17.22 & 6.8 \\
\hline $\mathrm{SiO}_{2}$ & 0.76 & 1.68 & 0.34 & 0.52 & 0.72 \\
\hline $\mathrm{TiO}_{2}$ & 0.44 & & 0.36 & 0.19 & 0.68 \\
\hline $\mathrm{MnO}$ & 0.28 & & 0.68 & 0.09 & 0.60 \\
\hline $\mathrm{CaO}$ & 0.00 & & 0.77 & 0.30 & \\
\hline $\mathrm{Na}_{2} \mathrm{O}$ & 0.07 & & & & \\
\hline $\mathrm{K}_{2} \mathrm{O}$ & 0.15 & & & & \\
\hline $\mathrm{P}_{2} \mathrm{O}_{5}$ & 0.10 & & & & \\
\hline $\mathrm{V}_{2} \mathrm{O}_{5}$ & 0.27 & & & & 0.20 \\
\hline & 98.48 & 100.16 & 99.77 & 100.27 & 98.80 \\
\hline $\mathrm{Cr}: \mathrm{Fe}$ & 0.99 & 1.76 & 1.12 & 2.56 & 1.41 \\
\hline
\end{tabular}

1. Chromite from Qagsse mountain, Fiskenæsset region (GGU No. 53282).

2. Chromite from lower group, eastern belt, Bushveld complex, South Africa (Kupferburger et al., 1937, p. 25).

3. Chromite concentrate from chromitite layer in anorthosite, Sittampundi complex, Madras, India (Subramaniam, 1956, p. 356).

4. Chromite from Moa district, Cuba (Guild, 1947).

5. Chromite from Kemi, North-western Finland (Vaasjoki and Heikkinen, 1961, p. 12). 
On comparing the chromite analyses in table $\mathrm{V}$ it is seen that the Fiskenæsset chromite is very similar in composition to the Sittampundi chromite. Although the chromite in the Kemi deposit has a higher $\mathrm{Cr}_{2} \mathrm{O}_{3}$ content than the Fiskenæsset chromite, it is worth noting that the Kemi ore contains some $30 \% \mathrm{Cr}_{2} \mathrm{O}_{3}$ on average, which is only a little more than the $\mathrm{Cr}_{2} \mathrm{O}_{3}$ content of the chromitite component of the Fiskenæsset ore. A plant for production of ferrochrome based on the Kemi ore is planned after beneficiation of the ore by magnetic separation (personal communication from Outokumpu company).

The low $\mathrm{Cr}: \mathrm{Fe}$ ratio of the Fiskenæsset chromite is interesting with regard to the proposed mode of origin as a stratiform body, as Thayer (1956, p. 33) states that the chromites from stratiform complexes, e.g. Bushveld, Stillwater, Bird River Complex (Bateman, 1945), are characteristically rich in iron and intermediate to low in their chromium oxide contents; this is also true for the Sittampundi chromite.

\section{d) Accessibility}

The Fiskenæsset region has a characteristic "skærgård" landscape with many islands and an undulating topography reaching to a height of $300 \mathrm{~m}$. Only in the eastern part is there higher terrain, Qagsse mountain north of Tasiussa bay being $1000 \mathrm{~m}$ high. Except in this highland region, the chromite horizons are located near the shore or only a few hundred metres from the coasts of the islands. The fjords are deep and allow easy access for shipping except for a few narrow inlets with strong currents caused by the $3 \mathrm{~m}$ difference between high and low tide. The ice conditions are some of the best in West Greenland, Fiskenæsset being accessible the whole year round; only the inner parts of the fjords may locally have a thin ice cover for $2-3$ months. There is snow from October to May, but this is normally less than $50 \mathrm{~cm}$ thick although on the high ground to the east it is, of course, more extensive.

The town of Fiskenæsset, with about 400 inhabitants, lies within the region and has frequent communication by ship with the capital, Godthåb, $150 \mathrm{~km}$ to the north. 


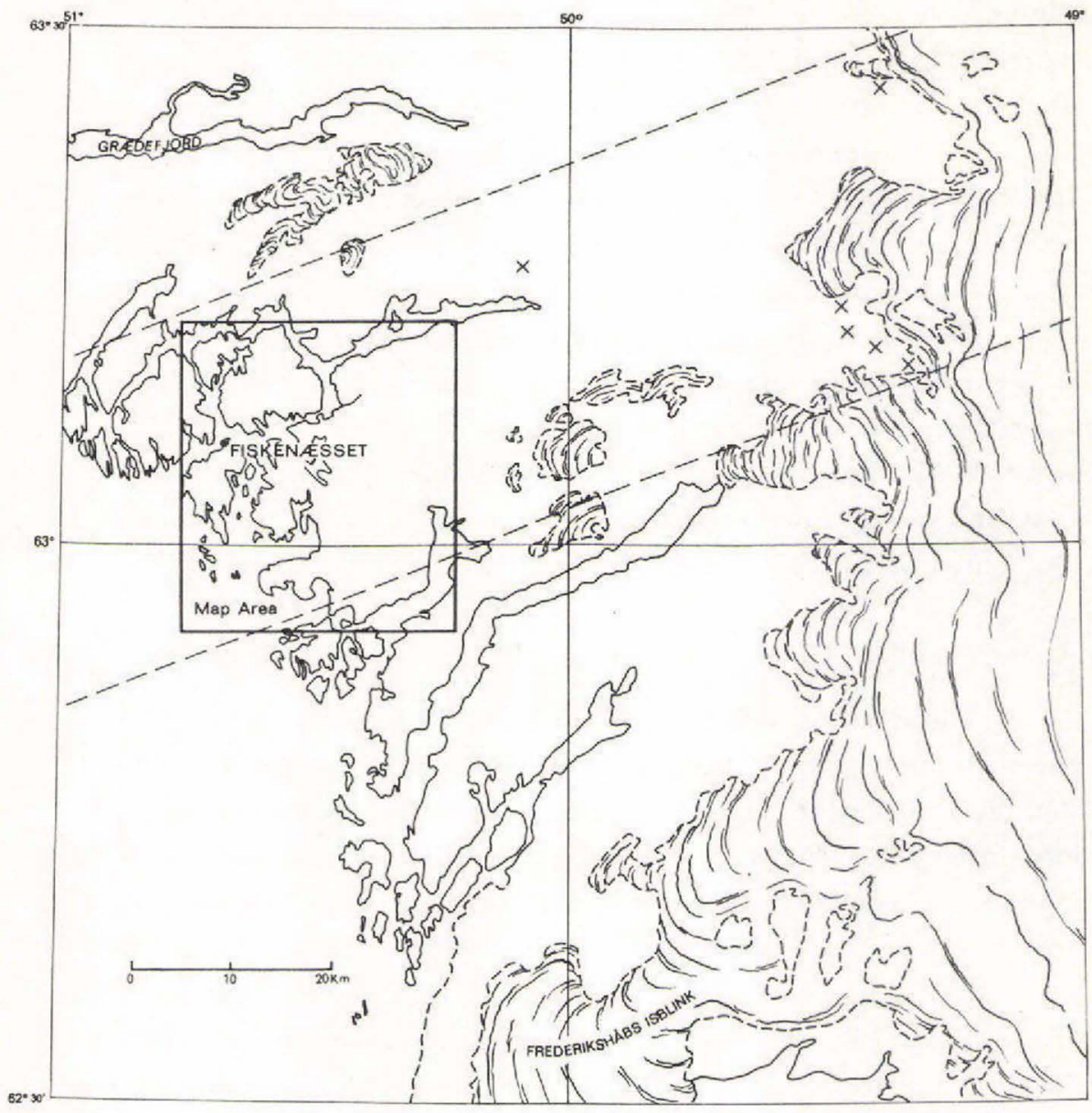

Fig. 10. Topographic sketch map of the region between Frederikshåb Isblink and Grædefjord showing the location of the area shown in map 1 and the probable eastward extent of the anorthosites, marked as a zone parallel to the major tectonic trend. ( $\mathrm{X}=$ Areas outside the map area where anorthosites can be seen on the aerial photographs). 
e) Further investigations

The region described covers an area of about $750 \mathrm{sq} \mathrm{km}$, although to the east there is a larger unknown area through which the anorthosite horizons must pass. As there is a general north-easterly structural trend, a zone can be demarcated in which the anorthosites, no doubt with their chromite horizons, can be expected to be found (see fig. 10). Within this zone, on the high ground to the east, only rare anorthosite horizons are visible on the aerial photographs, but near the inland ice there is a group of several distinct anorthosites. As the widest chromitite layers occur in the easternmost part of the region (west and north-east of Tasiussa bay), considerable deposits of chromite may be expected to occur further along the strike to the east. It is suggested that the initial step in future investigations could be an airborne geophysical and ground reconnaisance to ensure that the chromite-layered anorthosites do continue to the east as far as the ice. However, it should be noted that, although the chromite is moderately to strongly magnetic, the applicability of such an airborne survey would be seriously affected by the extreme relief which varies from 400 to $1400 \mathrm{~m}$ (see Hawkes, 1951).

In addition, the investigated area should be examined in more detail as the limited period of thirteen weeks did not enable all horizons to be studied for their full extent along the strike. Nevertheless, this cursory study has been sufficient to ascertain that the Fiskenæsset chromite deposits warrant a more comprehensive economic investigation.

There are two further features of possible economic interest: firstly, the sapphirine-bearing rocks associated with the complex are commonly rich in corundum, pink to red crystals of which reach up to $10 \mathrm{~cm}$ in length. Secondly, the anorthosites commonly weather to a white, desert-like, gravel which forms thick deposits over many horizons; this may well be suitable as a building material. 


\section{References}

Bateman, J.D. (1945) Composition of the Bird River chromite, Manitoba. Amer. Min. 30, 596-600.

Berthelsen, A. (1960) Structural studies in the Pre-Cambrian of Western Greenland, II Geology of Tovqussap Nuna. Medd. Grфnland, Bd. 123, Nr. 1, 223 pp.

Borgen, B.I. (in press) Analytical procedures used in the geochemical laboratory of the Survey. Rapp. Gr $\phi$ nlands geol. Unders., Nr. 10.

Guild, P. W. (1947) Petrology and structure of the Moa district, Oriente Province, Cuba. Am. Geophys. Union Trans. , 28, 218-246.

Hawkes, H. E. Jr. (1951) Magnetic exploration for chromite. Bull. geol. Surv. Amer. 973A, 1-20.

Kupferburger, W. et al. (1937) The chromite deposites of the Bushveld igneous complex, Transvaal, Union of South Africa. Dept. Mines Bull. 10 (Geol. series), 48 pp.

Malhotra, P.D. and Prasada Rao, G. H.S. V. (1963) Investigations of the chemical composition of Indian chromites. Rec. geol. Surv. India, 93, 215-248.

Ramdohr, P. (1960) Die Erzmineralien und ihre Verwachsungen. Akademie-Verlag, Berlin, 875 pp.

Sørensen, H. (1955) On sapphirine from west Greenland. Medd. Grønland, Bd. 137, Nr. 1, 32 pp.

Subramaniam, A. P. (1956) Mineralogy and petrology of the Sittampundi Complex, Salem district, Madras State, India. Bull. geol. Soc. Amer., 67, 317-390.

Thayer, T. P. (1956) Mineralogy and geology of chromium. In Udy, M.J. (Edit.) Chromium, v. 1, 14-52. New York: Reinhold Publ. Corp.

Vaasjoki, O. and Heikkinen, A. (1961) On the chromites of the Kemi deposits, Northwestern Finland. Bull. Comm. geol. Finlande, No. 194, 26 pp.

Windley, B. F. (in press) On the classification of the West Greenland anorthosites. Geol. Rundsch. 
Folded maps:-

Map 1: Geological map of the Fiskenæsset region.

Map 2: Detailed map of the chromite horizon from central Qeqertarssuatsiaq.

Map 3: Detailed map of the chromite horizons from east Qeqertarssuatsiaq. 

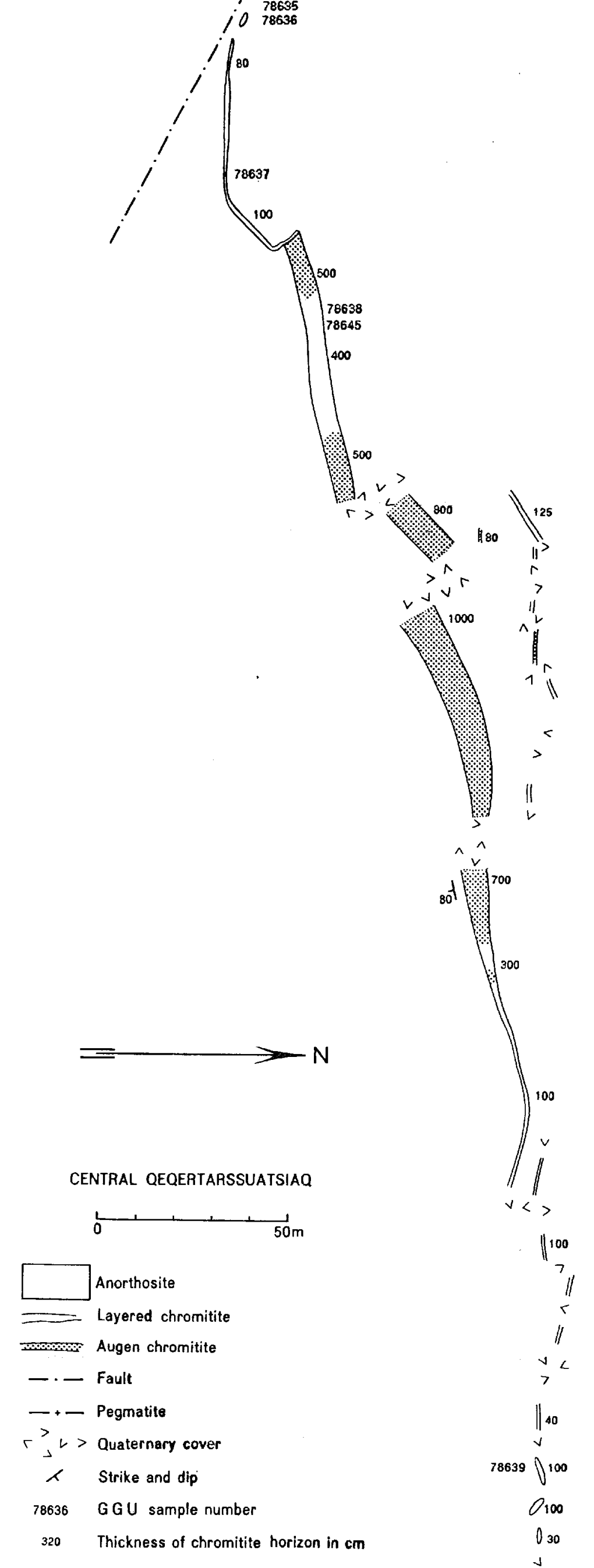


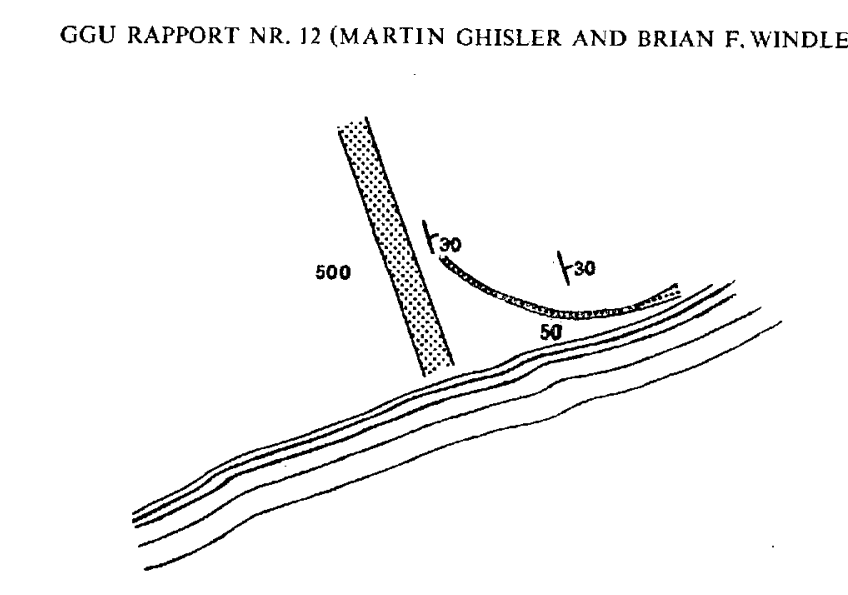

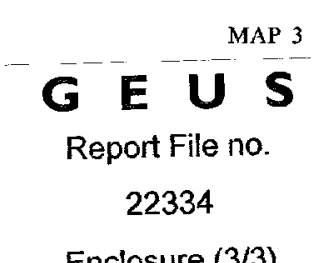

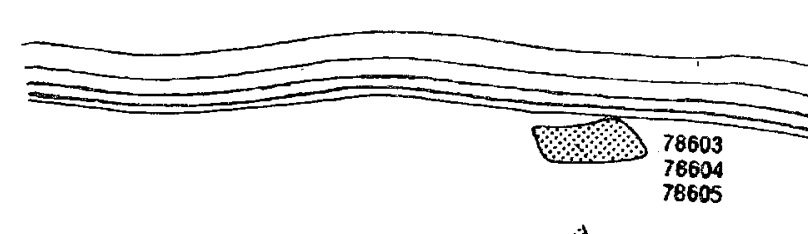

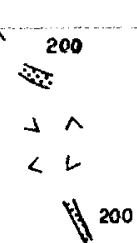
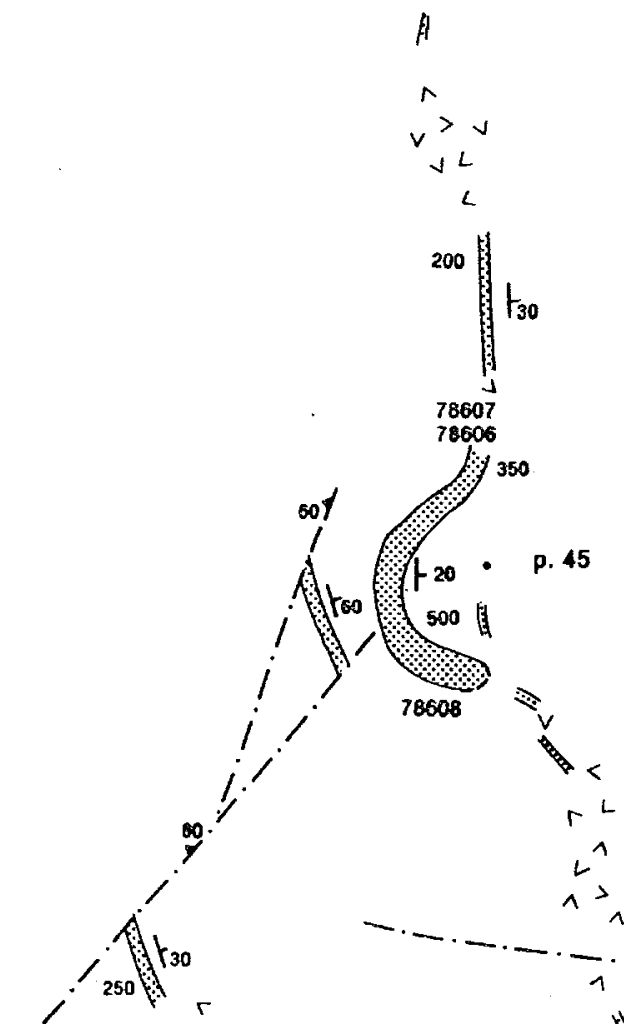

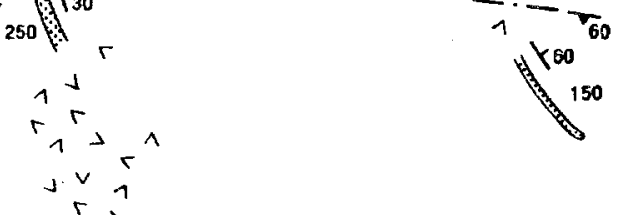

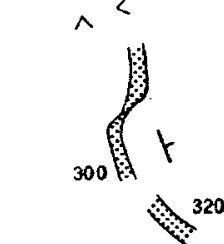
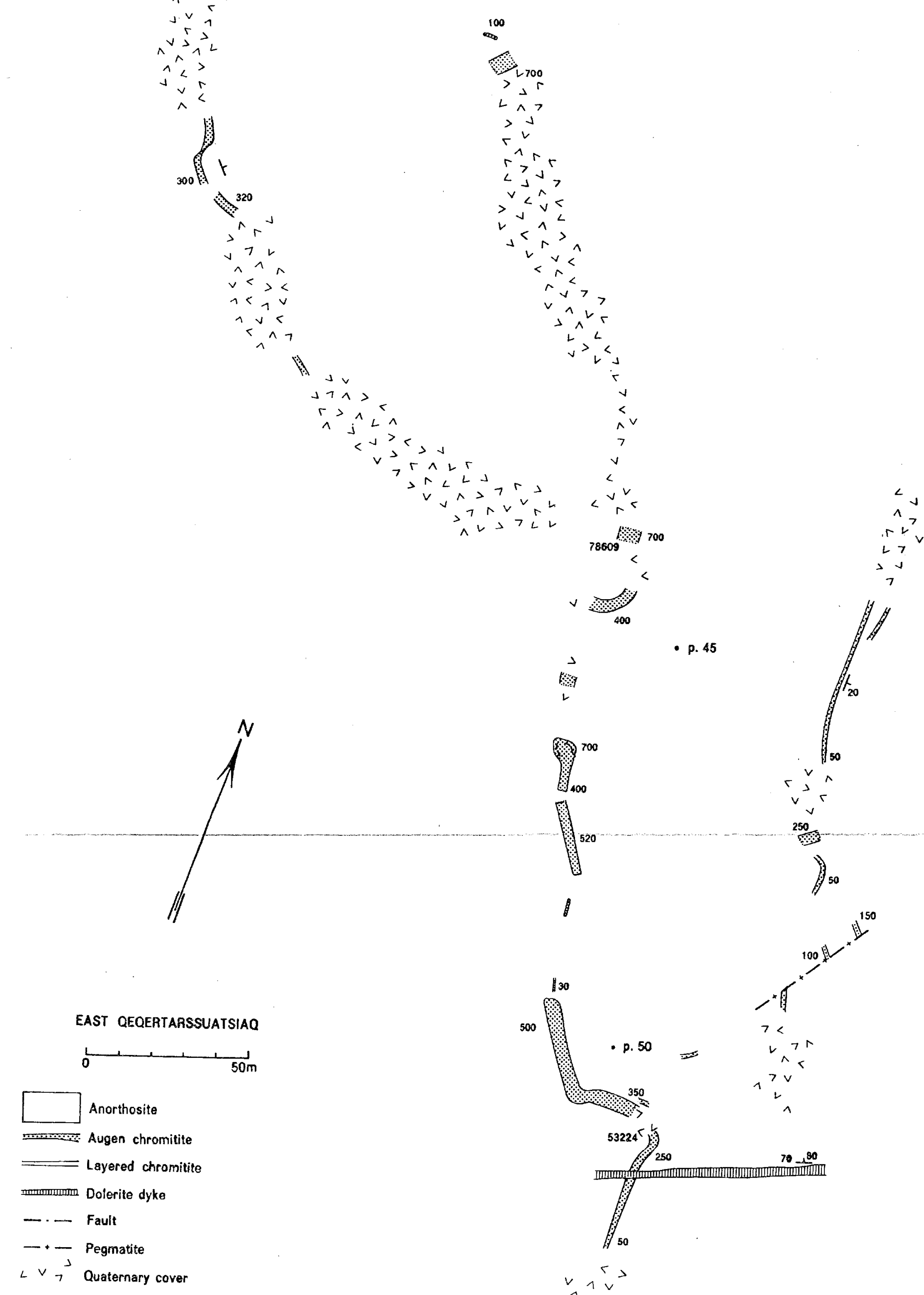

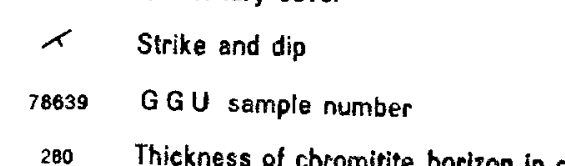
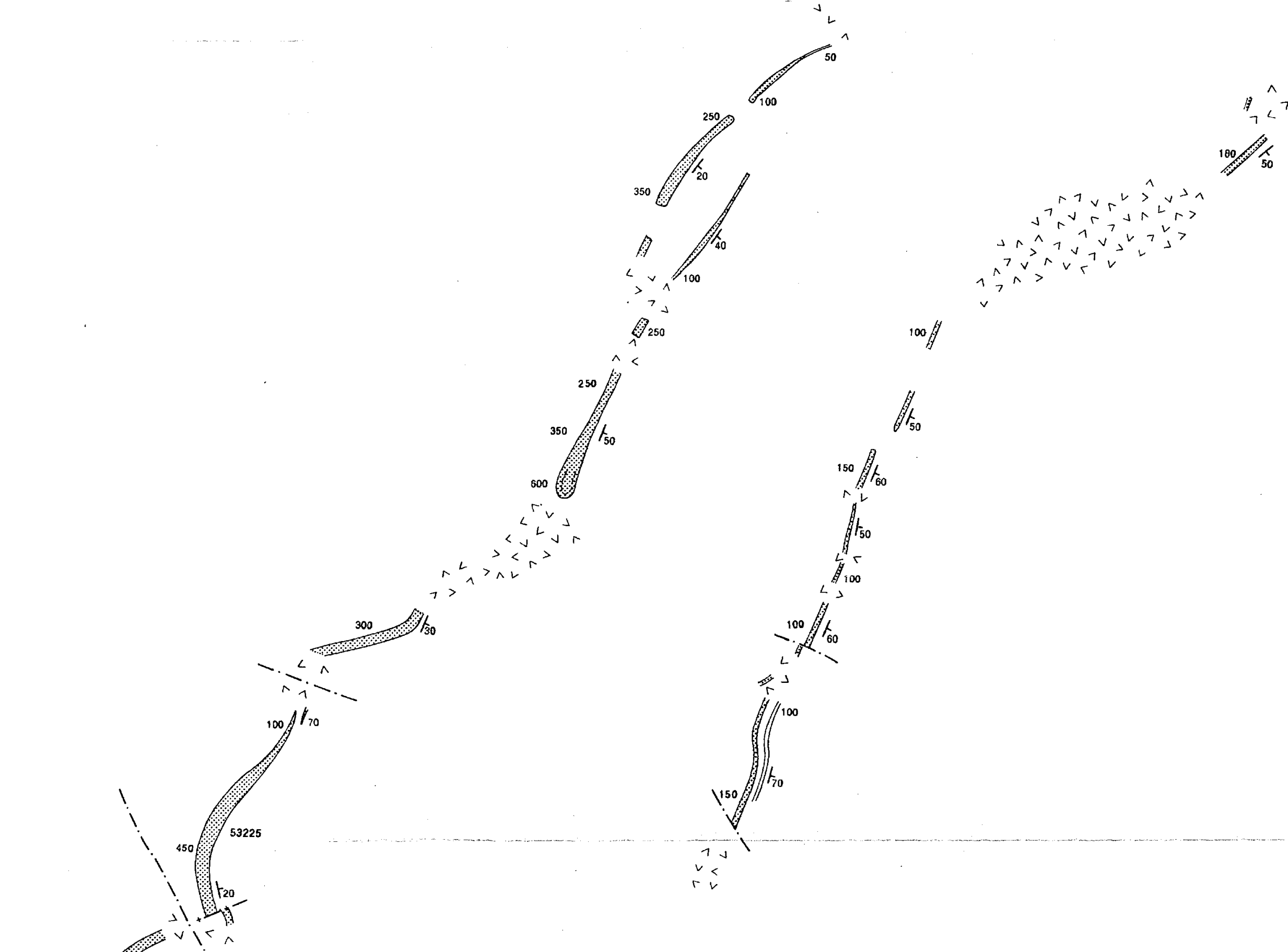

Hro 